\title{
Economic Contributions of Florida's Agricultural, Natural Resource, and Food and Kindred Product Manufacturing, Distribution, and Service Industries in $2007^{1}$
}

Alan W. Hodges and Mohammad Rahmani ${ }^{2}$

\section{Introduction}

The state of Florida has nearly 24 million acres (36,000 square miles) in forests, croplands, and ranches, which is about two-thirds of its total land area. The agricultural and natural resource industries produce food, fiber, and mineral commodities. They are linked to a broad range of other economic sectors for food and kindred product manufacturing, wholesale and retail distribution, input supplies, support services, and nature-based recreation. In addition to farming, forestry, fisheries, and mining, this grouping of agricultural and natural resource industries includes other diverse activities such as fertilizer manufacturing, sawmills, fruit and vegetable processing, landscaping, wholesale food distributors, retail food stores, restaurants and other food service establishments, retail garden centers, pest control, golf courses, and recreational fishing.

This report provides estimates of these industries' economic contributions to Florida in 2007, updating a previous study for 2006 (Hodges, Rahmani and Mulkey 2008).

\section{Methods}

Data for this analysis were obtained from the IMPLAN Professional database for Florida counties for 2001-07 (Minnesota IMPLAN Group) and from other special studies conducted by the authors. These data were derived from the National Income and Product Accounts for the United States (United States Department of Commerce 2008). Over 80 individual industry sectors in Florida were identified as related to agriculture and natural resource commodity production, input supply and supporting services, food and kindred product manufacturing and distribution, and nature-based recreation. A list of industry groups and individual sectors included in the analysis is shown in Table 1. Economic contributions were also evaluated for several recognizable industry commodity groups that have linkages between the production and processing/manufacturing sectors, including environmental horticulture (nursery and greenhouse production, landscape services, and retail lawn and garden centers); fruit and vegetable farming and processing; forestry, logging and forest product manufacturing; sugarcane and refined sugar

1. This is EDIS document FE800, a publication of the Food and Resource Economics Department, Florida Cooperative Extension Service, Institute of Food and Agricultural Sciences, University of Florida, Gainesville, FL. Published April 2009. Please visit the EDIS website at http://edis.ifas.ufl.edu.

2. Alan W. Hodges, extension scientist, and Mohammad Rahmani, coordinator of economic analysis, Food and Resource Economics Department, Florida Cooperative Extension Service, Institute of Food and Agricultural Sciences, University of Florida, Gainesville, FL.

The Institute of Food and Agricultural Sciences (IFAS) is an Equal Opportunity Institution authorized to provide research, educational information and other services only to individuals and institutions that function with non-discrimination with respect to race, creed, color, religion, age, disability, sex, sexual orientation, marital status, national origin, political opinions or affiliations. U.S. Department of Agriculture, Cooperative Extension Service, University of Florida, IFAS, Florida A. \& M. University Cooperative Extension Program, and Boards of County Commissioners Cooperating. Millie Ferrer-Chancy, Interim Dean 
manufacturing; livestock and animal products manufacturing; fishing; and seafood products.

The total regional economic impacts for each sector were estimated using models developed with the IMPLAN Professional software for social accounting and impact analysis. This system enables the construction of input-output models and social accounting matrices that represent transactions among industry sectors, households, and governments within a local or regional economy. These models account for industrial commodity production, employment, labor and property income, consumption, regional trade, transfer payments such as welfare and retirement, and capital investment, etc. Economic multipliers derived for each industry capture the secondary effects of new money to the region that generates further economic activity as it is re-spent in the local economy (Miller and Blair 1985). Indirect effects multipliers represent the economic activity generated in the supply chain by purchases of intermediate inputs from vendor firms, while induced effects multipliers represent the impacts of spending by industry employee households and by local, state, and/or federal governments. The indirect and induced multipliers were applied only to foreign and domestic exports, or sales outside the state of Florida. The total economic impacts are the sum of direct effects of industry sales or employment, plus the indirect and induced effects. Although the estimates of this analysis are referred to as economic impacts, these values may be better understood as economic contributions because they represent ongoing economic activity of existing industries, rather than a net change in activity resulting from external influences (Watson et al. 2007).

The measures of economic impacts reported include output, or revenue; value added (income); employment (full-time, part-time, or seasonal positions); labor income; property income; and indirect business taxes paid to local, state, and/or federal governments. Value added is a broad measure of economic activity that is comparable to the Gross Domestic Product (GDP) at the national level, and represents the net income created by an industry, comprising labor and property income, indirect business taxes, and capital consumption. Value added is equivalent to the difference between industry revenues and intermediate inputs purchased from other sectors. A glossary of economic impact analysis terminology is provided in the Appendix.

Regional models were developed for the state of Florida, which included nine economic regions and all 67 counties in the state. The nine regions were defined based on metropolitan areas, employee commuting patterns, and other economic data from the 2000 Census (Johnson and Kort 2004). Note that some Georgia counties included in the North Florida regions were not evaluated in this analysis, and that there were slight discrepancies in the results of the analysis at the state, region, and county levels due to differences in trade flows and accounting adjustments. The regional economic models were constructed to include social/institutional accounts for households; local, state and federal governments; and capital investment.

Adjustments were made to the data for exports in some industry sectors based on information from primary surveys in previous studies (Hodges et al. 2006; Hodges, Rahmani, and Mulkey 2008). Values for some activities that are not explicitly represented in the model were estimated as a share of their parent sector based on previous studies and other economic data: landscape services and pest control services were 49 percent and 15 percent, respectively, of services to buildings; wholesale food distribution was 20 percent of wholesale trade; garden centers were 19 percent of building materials and garden stores; and golf courses and recreational fishing were 48 percent and 10 percent, respectively, of amusement and recreation services.

Values for 2001 through 2007 were expressed in 2008 U.S. dollars using the mid-year (July) indices for the Gross Domestic Product (GDP) Implicit Price Deflator (United States Department of Commerce 2008), which is a broad measure that accounts for the effects of price changes in the measurement of GDP. IMPLAN data were unavailable for 2005. Note that results for prior years were revised in light of new information, so findings presented here do not match those previously reported for 2001 to 2006 (Hodges, Rahmani, and Mulkey 2008). 


\section{Results}

\section{Economic Contributions by Industry Groups and Sectors}

Economic contributions by major industry groups and specific industry sectors in Florida in 2007 are shown in Table 1 and summarized in Figures 1,2 , and 3. The industries are categorized into seven major groups: crop, livestock, forestry and fisheries production; mining; agricultural inputs and services; food and kindred products manufacturing; forest products manufacturing; food and kindred products distribution; and nature-based recreation. Results are reported below for each major group; all groups combined; and all groups, excluding food and kindred products distribution. the industry was 1.37 million full-time and part-time jobs, while total employment impacts, including multiplier effects, were estimated at 1.87 million jobs (Figure 1). The direct value-added contribution of these industries was $\$ 58.62 \mathrm{Bn}$, and total value-added impacts were $\$ 93.38 \mathrm{Bn}$. The total labor (earned) income impact of employee wages and benefits and business proprietor income was $\$ 60.51 \mathrm{Bn}$. Property income impacts, such as rents and dividends, were $\$ 22.40 \mathrm{Bn}$. Indirect business tax impacts paid to local, state, and federal governments were $\$ 10.47 \mathrm{Bn}$.

Excluding the sectors for food and kindred products distribution, such as restaurants, food stores and wholesalers, total economic values were as follows: output, $\$ 62.67 \mathrm{Bn}$; exports, \$33.13 Bn;

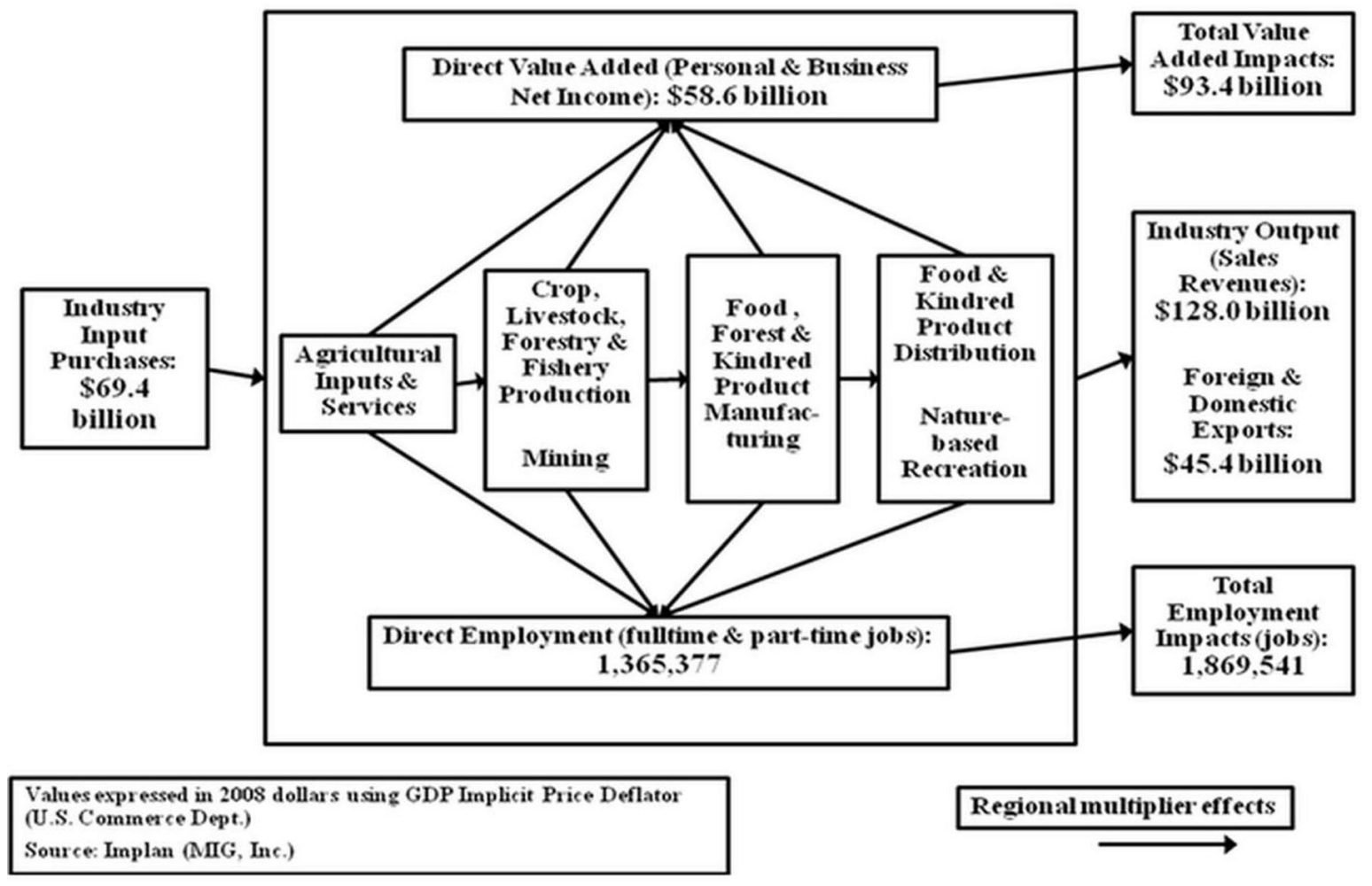

Figure 1. Structure of economic activity in Florida agricultural, natura resource, and food and kindred product manufacturing, distribution, and service industries in 2006.

Total industry output or sales in 2007 were about $\$ 128.01$ billion (Bn), stated in 2008 U.S. dollars. Total foreign and domestic exports of goods and services to customers outside of Florida were $\$ 45.42$ $\mathrm{Bn}$. As a result of the indirect and induced multiplier effects from export sales, the total output impacts were estimated at $\$ 187.67 \mathrm{Bn}$. Direct employment in output impacts, \$103.63 Bn; direct employment, 418,003 jobs; employment impacts, 763,065 jobs; direct value added, $\$ 21.29 \mathrm{Bn}$; value-added impacts, \$44.77 Bn; labor income impacts, \$28.04 Bn; property income impacts, $\$ 13.16 \mathrm{Bn}$; and indirect business tax impacts, $\$ 3.58 \mathrm{Bn}$ (Table 1). 


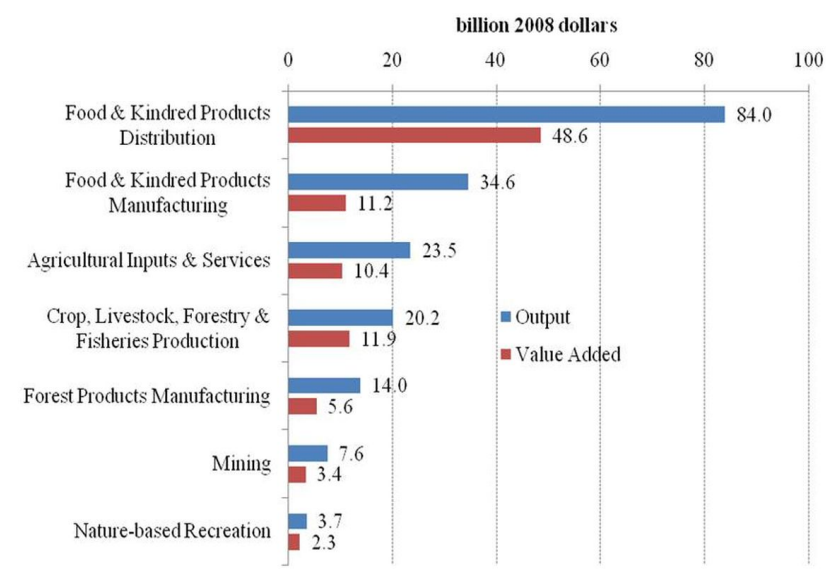

Figure 2. Output and value-added impacts of agricultural, natural resource, and food and kindred product manufacturing, distribution, and service industries in Florida in 2007.

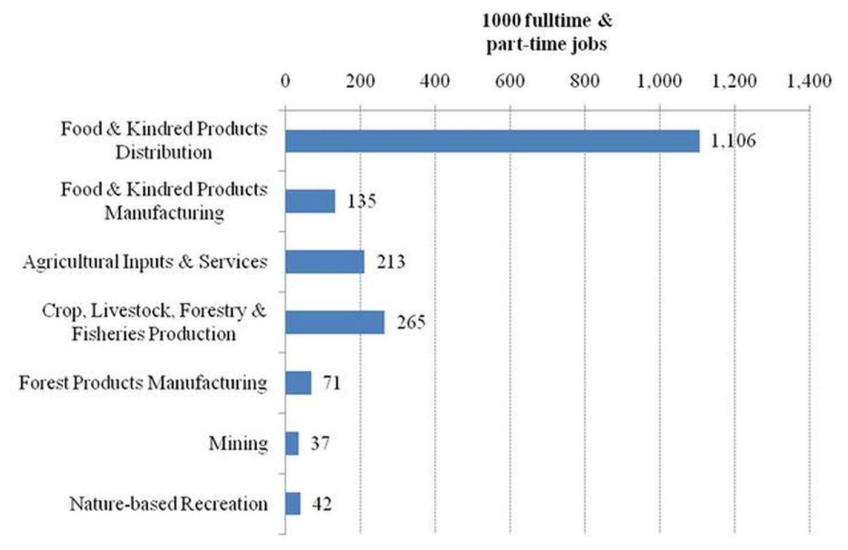

Figure 3. Employment impacts of agricultural, natural resource, and food and kindred product manufacturing, distribution, and service industries in Florida in 2007.

\section{Crop, livestock, forestry, and fisheries} production includes sectors for production of basic unrefined food and fiber commodities. In 2007, total output was $\$ 11.30 \mathrm{Bn}$, exports were $\$ 6.52 \mathrm{Bn}$, output impacts were $\$ 20.23 \mathrm{Bn}$, direct value added was $\$ 6.48 \mathrm{Bn}$, value-added impacts were $\$ 11.90 \mathrm{Bn}$, direct employment was 172,482 jobs, and total employment impacts were 264,964 jobs (Table 1, Figures 2 and 3). Among individual industry sectors in this group, the highest value-added and employment impacts were in fruit farming (\$2.59 Bn, 50,189 jobs), greenhouse, nursery and floriculture production ( $\$ 2.55 \mathrm{Bn}, 36,223$ jobs), support activities for agriculture and forestry ( $\$ 2.03 \mathrm{Bn}, 86,054$ jobs), and vegetable and melon farming $(\$ 1.75 \mathrm{Bn}, 25,288$ jobs). Large value-added and employment impacts were also registered for the sectors of forestry and timber tracts (\$991 Million [Mn], 14,062 jobs), commercial logging ( $\$ 503 \mathrm{Mn}, 4,649$ jobs), and sugarcane farming ( $\$ 351 \mathrm{Mn}, 16,150$ jobs). Value-added impacts of $\$ 100$ to $\$ 200$ million were observed for dairy farming, beef cattle ranching and farming, poultry and egg production, commercial fishing, and all other crop farming.

Agricultural inputs and services includes a variety of functions required as inputs or supporting activities for agricultural operations or management of buildings and grounds. Output impacts in 2007 by this group totaled $\$ 23.55 \mathrm{Bn}$, value-added impacts were $\$ 10.42 \mathrm{Bn}$, direct employment was 137,880 jobs, and employment impacts were 213,274 jobs (Table 1, Figures 2 and 3). Among the leading sectors in this group, landscape services had value-added impacts of $\$ 4.02 \mathrm{Bn}$ and employment impacts of 104,458 jobs, followed by fertilizer manufacturing (\$3.18 Bn, 37,753 jobs), veterinary services ( $\$ 1.59$ $\mathrm{Bn}, 35,363$ jobs), pest control services ( $\$ 1.23 \mathrm{Bn}$, 31,977 jobs), and pesticide and other agricultural chemical manufacturing ( $\$ 347 \mathrm{Mn}, 3,074$ jobs). Other minor sectors in this group included farm machinery and equipment manufacturing, and lawn and garden equipment manufacturing.

Mining is a natural-resource-based activity for the extraction of basic mineral commodities such as oil, natural gas, stone, sand, gravel, clay, phosphate, and a variety of metals. In 2007, the mining industries in Florida collectively had direct output of $\$ 4.41 \mathrm{Bn}$, exports of $\$ 2.22 \mathrm{Bn}$, output impacts of $\$ 7.58 \mathrm{Bn}$, value-added impacts of $\$ 3.40 \mathrm{Bn}$, direct employment of 11,877 jobs, and employment impacts of 37,207 jobs (Table 1, Figures 2 and 3). The sector extraction of oil and natural gas had value-added impacts of $\$ 1.17 \mathrm{Bn}$ and generated employment impacts of 15,862 jobs. Other individual sectors with significant value-added impacts included mining and quarrying stone ( $\$ 860 \mathrm{Mn})$; mining and quarrying other nonmetallic minerals ( $\$ 481 \mathrm{Mn})$; mining and quarrying sand, gravel, and clay $(\$ 335 \mathrm{Mn})$; and drilling oil and gas wells (\$212 Mn).

Food and kindred products manufacturing industries convert unrefined agricultural commodities to food and fiber products for consumption or use by society at large. In 2007, this group of industries in 
Florida had a direct output of $\$ 23.03 \mathrm{Bn}$, including exports of $\$ 10.63 \mathrm{Bn}$; output impacts of $\$ 34.64 \mathrm{Bn}$; value-added impacts of $\$ 11.17 \mathrm{Bn}$; direct employment of 42,437 jobs; and total employment impacts of 135,200 jobs (Table 1, Figures 2 and 3). This large industry group includes 34 individual sectors, of which the highest value-added and employment impacts were for soft drink and ice manufacturing ( $\$ 2.37 \mathrm{Bn}, 30,810$ jobs), tobacco product manufacturing ( $\$ 1.95 \mathrm{Bn}, 8,560$ jobs), fruit and vegetable canning, pickling, and drying $(\$ 1.76$ $\mathrm{Bn}, 20,986$ jobs), sugar manufacturing ( $\$ 1.14 \mathrm{Bn}$, 20,687 jobs), breweries ( $\$ 811 \mathrm{Mn}, 7,854$ jobs) and distilleries ( $\$ 631 \mathrm{Mn}, 5,461$ jobs), frozen food manufacturing ( $\$ 517 \mathrm{Mn}, 7,583$ jobs), and bread and bakery product manufacturing( $\$ 328 \mathrm{Mn}, 7,736$ jobs $)$. Other sectors with significant value-added impacts included seafood product preparation and packaging (\$158 Mn), animal slaughtering ( $\$ 156 \mathrm{Mn})$, fluid milk and butter manufacturing ( $\$ 155 \mathrm{Mn})$, other animal food manufacturing ( $\$ 146 \mathrm{Mn}$ ), and snack food manufacturing ( $\$ 107 \mathrm{Mn})$.

Forest products manufacturing is a group of manufacturing industries for the processing of raw timber or wood into finished wood and paper products. In 2007, this industry group had direct output valued at $\$ 8.19 \mathrm{Bn}$; export sales of $\$ 4.85 \mathrm{Bn}$; output impacts of $\$ 13.97 \mathrm{Bn}$; direct employment of 26,399 jobs; employment impacts of 70,696 jobs; and value-added impacts of $\$ 5.56 \mathrm{Bn}$, including labor income impacts of $\$ 3.67 \mathrm{Bn}$, other property income impacts of $\$ 1.55 \mathrm{Bn}$, and indirect business tax impacts of $\$ 337 \mathrm{Mn}$ (Table 1, Figures 2 and 3). Leading sectors within this group for value-added and employment impacts were paper mills $(\$ 1.04 \mathrm{Bn}$, 11,746 jobs), paperboard container manufacturing (\$894 Mn, 11,857 jobs), sanitary paper product manufacturing ( $\$ 658 \mathrm{Mn}, 6,611$ jobs), engineered wood member and truss manufacturing $(\$ 620 \mathrm{Mn}$, 9,354 jobs), paperboard mills ( $\$ 605 \mathrm{Mn}, 7,054$ jobs), and pulp mills ( $\$ 433 \mathrm{Mn}, 5,053$ jobs). Other sectors with significant value-added impacts included wood window and door manufacturing ( $\$ 355 \mathrm{Mn})$, stationary product manufacturing $(\$ 270 \mathrm{Mn})$, sawmills and wood preservation (\$229 Mn), and coated and laminate paper packaging $(\$ 145 \mathrm{Mn})$.
Nature-based recreation includes recreational activities that are generally tied to natural resources or managed landscapes, such as golf, recreational fishing, and hunting/trapping. In 2007, this industry group in Florida had a total output of $\$ 1.97 \mathrm{Bn}$; exports or sales to Florida visitors of $\$ 1.07 \mathrm{Bn}$; output impacts of $\$ 3.67 \mathrm{Bn}$; direct employment of 26,929 jobs; employment impacts of 41,724 jobs; and value-added impacts of \$2.32 Bn (Table 1 and Figures 2 and 3). Among individual sectors, golf courses had value-added impacts of \$1.64 Bn and employment impacts of 31,571 jobs, followed by recreational fishing ( $\$ 341 \mathrm{Mn}, 6,577$ jobs), and commercial hunting and trapping ( $\$ 345 \mathrm{Mn}, 3,575$ jobs).

\section{Food and kindred products distribution} includes activities for wholesale and retail trade in agricultural and related products. This large group of industry sectors is only indirectly related to agriculture and natural resources because it serves to deliver products to final consumers, but it is included here for perspective on the scope of the entire market chain for food and kindred products. In 2007, this industry group in Florida had total output of $\$ 65.34$ $\mathrm{Bn}$; exports of $\$ 12.29 \mathrm{Bn}$; output impacts of $\$ 84.04$ Bn; direct employment of 947,374 jobs; employment impacts of 1,106,477 jobs; and value-added impacts of $\$ 48.61 \mathrm{Bn}$, including labor income impacts of $\$ 32.48 \mathrm{Bn}$, other property income impacts of $\$ 9.24$ $\mathrm{Bn}$, and indirect business tax impacts of $\$ 6.90 \mathrm{Bn}$ (Table 1 and Figures 2 and 3). Collectively, this group represented about 52 percent of the total value-added impacts and 59 percent of the employment impacts for the entire agriculture, natural resources, and related industries defined in this report. Among individual sectors within this group, food services and drinking places (restaurants and bars) had by far the greatest value-added impacts ( $\$ 26.72 \mathrm{Bn})$ and employment impacts (746,925 jobs), followed by wholesale trade in food and kindred products $(\$ 12.27$ $\mathrm{Bn}, 125,708$ jobs), food and beverage stores ( $\$ 8.50$ Bn, 215,695 jobs), and retail lawn and garden centers (\$1.12 Bn, 18,148 jobs). 


\section{Economic Contributions by Commodity Groups}

Economic contributions were also evaluated for food, fiber, and mineral commodity groups having market chain linkages between producers, manufacturers, and service sectors. In this section, some sectors are regrouped to reflect these linkages, with results summarized in Figures 4 and 5. Environmental horticulture, which includes the sectors nursery and greenhouse production, landscape services, and retail lawn and garden stores, had value-added impacts of \$7.68 Bn and employment impacts of 158,829 jobs. Forestry and forest products, which includes the sectors for forestry and timber tracts, logging, and 16 forest product manufacturing sectors, had value-added impacts of $\$ 7.05 \mathrm{Bn}$ and employment impacts of 89,407 jobs. Fruit and vegetable farming and processing, including sectors for frozen food manufacturing and fruit and vegetable canning, pickling and drying, as well as fruit farming and vegetable and melon farming, had value-added impacts of $\$ 6.61 \mathrm{Bn}$ and employment impacts of 104,082 jobs. Sugarcane farming and refined sugar manufacturing had value-added impacts of $\$ 1.49 \mathrm{Bn}$ and employment impacts of 36,837 jobs. Livestock and dairy farming and animal products manufacturing, including the processing sectors animal slaughtering, poultry processing, cheese manufacturing, and ice cream manufacturing, had total value-added impacts of $\$ 1.22 \mathrm{Bn}$ and employment impacts of 27,960 jobs. Fishing and seafood products had value-added impacts of \$297 Mn and employment impacts of 10,986 jobs. The commodity group grain and oilseed farming and processing had value-added and employment impacts of \$146 Mn and 1,936 jobs, respectively.

\section{Economic Contributions in Florida Regions and Counties}

Regional impacts of agriculture, natural resources, food manufacturing, distribution, and related service industries in 2007 were evaluated for nine economic regions of Florida, as illustrated in Figure 6, with results summarized in Table 2 and Figures 7 and 8 . The region with the highest value-added and employment impacts was Miami-Ft. Lauderdale (\$29.82 Bn, 596,271 jobs), followed by

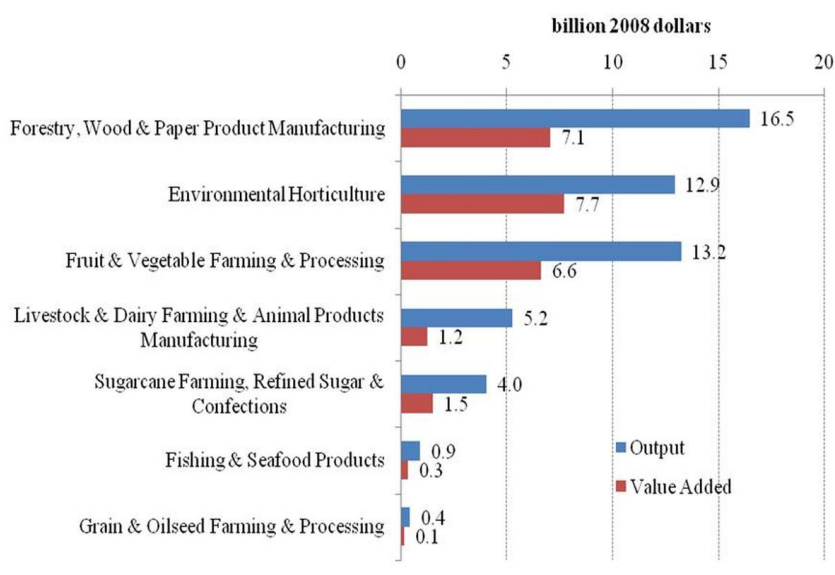

Figure 4. Output and value-added impacts of food and fiber commodity groups in Florida in 2007.

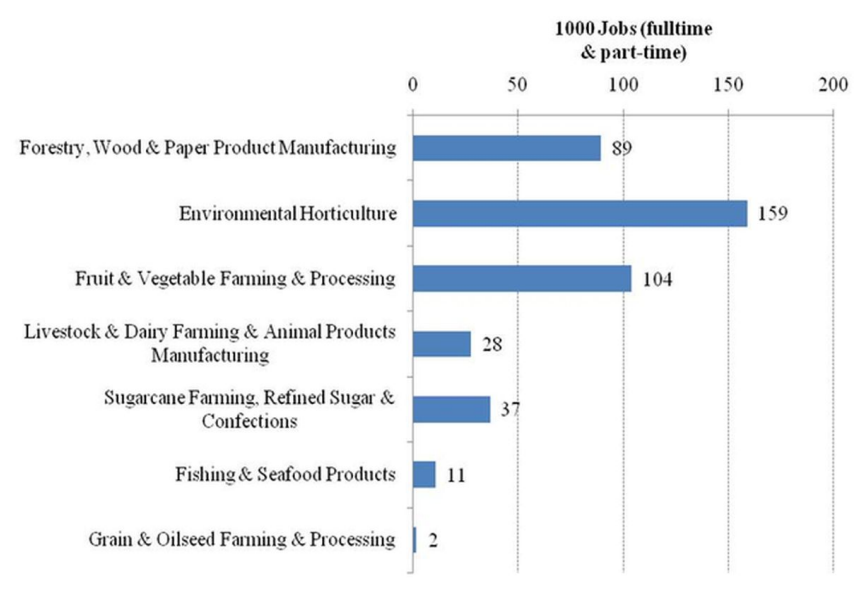

Figure 5. Employment impacts of food and fiber commodity groups in Florida in 2007.

Orlando (\$22.04 Bn, 458,740 jobs), Tampa-St. Petersburg (\$15.39 Bn, 301,786 jobs), Jacksonville (\$10.66 Bn, 166,391 jobs), Sarasota-Bradenton (\$8.41 Bn, 184,877 jobs), Pensacola (\$2.43 Bn, 56,959 jobs), Gainesville ( $\$ 2.35 \mathrm{Bn}, 51,758$ jobs), Tallahassee ( $\$ 1.95$ Bn, 43,047 jobs), and Panama City (\$1.24 Bn, 26,290 jobs.

Economic impacts were also evaluated for all 67 counties in Florida as shown in Table 3 and summarized in Figure 9. The largest counties in terms of value-added impacts and employment impacts in 2007 were Miami-Dade ( $\$ 11.37$ Bn, 204,105 jobs), Hillsborough (\$9.46 Bn, 172,481 jobs), Duval (\$7.84 Bn, 112,440 jobs), Orange (\$7.81 Bn, 147,289 jobs), Palm Beach ( $\$ 6.94$ Bn, 147,783 jobs), Broward (\$6.87 Bn, 137,512 jobs), Pinellas ( $\$ 4.78$ Bn, 93,861 jobs), and Polk ( $\$ 4.41 \mathrm{Bn}, 78,454$ jobs). Counties with value-added impacts exceeding $\$ 2$ billion were Lee (\$2.45 Bn), Collier (\$2.11 Bn), and Manatee 


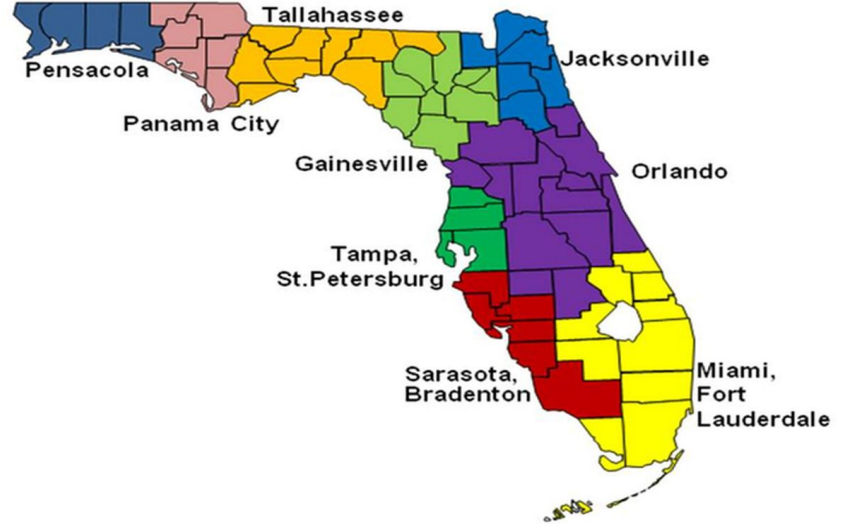

Figure 6. Economic regions of Florida.

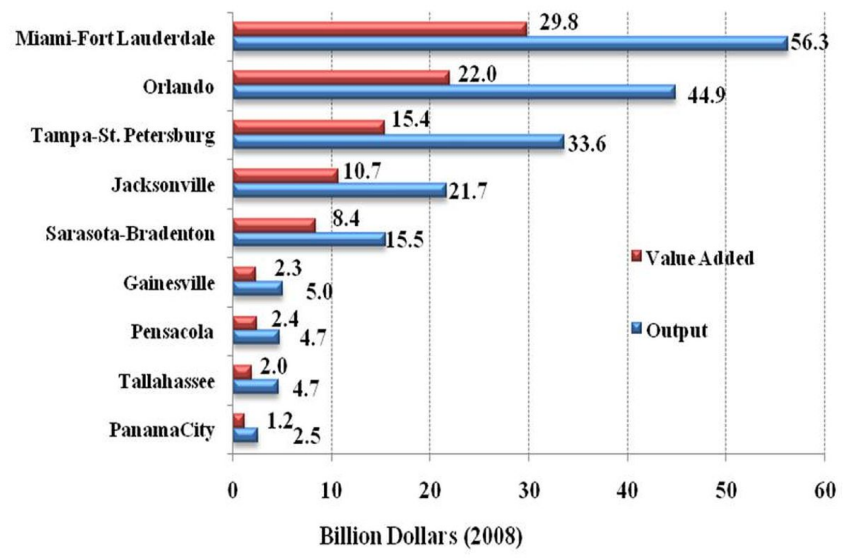

Figure 7. Output and value-added impacts in Florida regions by agricultural, natural resource, and food and kindred product manufacturing, distribution, and service industries in 2007.

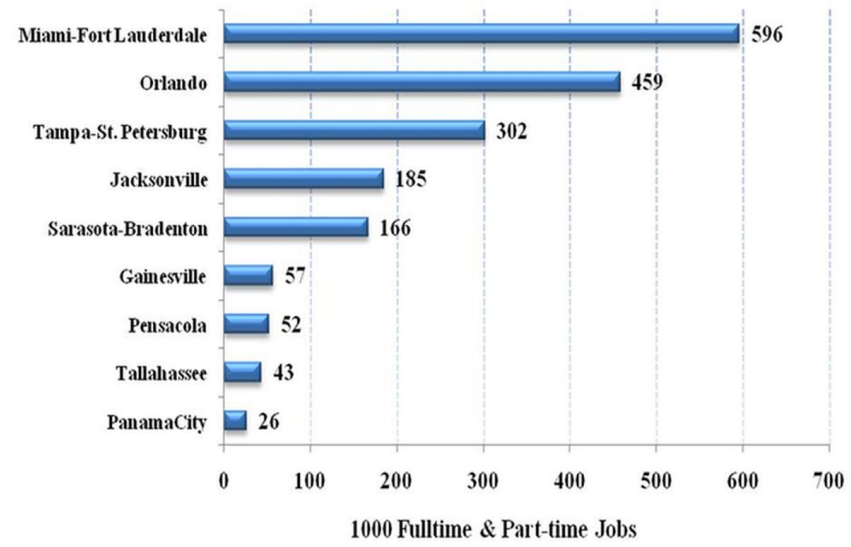

Figure 8. Employment impacts in Florida regions by agricultural, natural resoure, and food and kindred product manufacturing, distribution, and service industries in 2007.

$(\$ 2.05 \mathrm{Bn})$, and counties with value-added impacts exceeding $\$ 1$ billion included Brevard $(\$ 1.22 \mathrm{Bn})$, Escambia (\$1.16 Bn), Marion \$1.07 Bn), Sarasota
(\$1.24 Bn), Seminole (\$1.67 Bn), St. Lucie (\$1.08 $\mathrm{Bn})$, and Volusia (\$1.36 Bn).

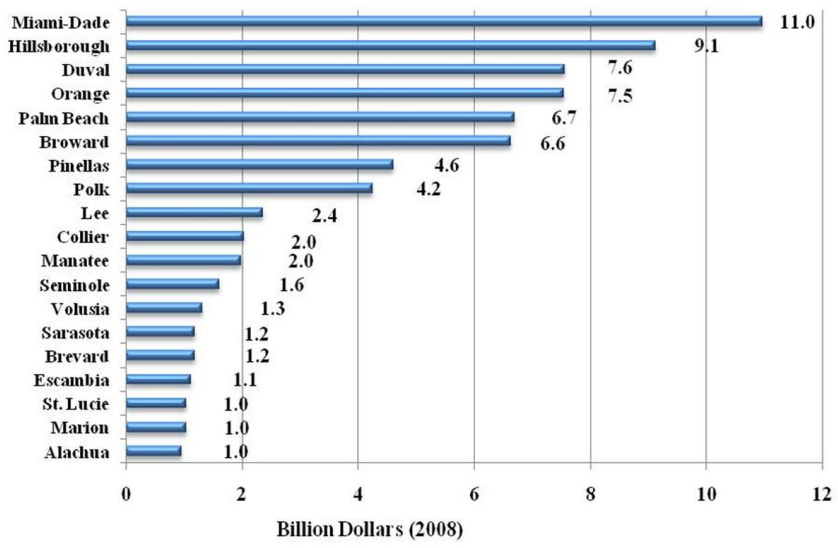

Figure 9. Value-added impacts in the twenty largest Florida counties by agriculture, natural resource, and food and kindred product manufacturing, distribution, and service industries in 2007.

\section{Economic Contribution Trends for 2001 through 2007}

In addition to the economic contributions in 2007, it is important to understand how these values have changed over time. Trends in economic impacts of these industries between 2001 and 2007 are shown in Tables 4 and 5 and Figures 10 and 11. Note again that all values were adjusted for inflation to express in constant 2008 U.S. dollars. Total value-added impacts grew from $\$ 76.48 \mathrm{Bn}$ in 2001 to $\$ 93.38 \mathrm{Bn}$ in 2007 , representing an average annual growth rate of 3.7 percent. Total output impacts grew by an average of 5.4 percent annually, and total employment impacts increased by 1.7 percent annually. For 2006-07, there was a slightly higher growth rate in value-added impacts (4.1\%) and substantially higher growth in employment impacts (5.3\%) (Table 4). Note that these trends may reflect changes in the structure of the Florida economy, as well as changes in industry activity and commodity prices.

Among industry groups, average annual growth in value-added impacts for the 2001 to 2007 period was highest for mining (19.2\%) and crop, livestock, forestry, and fishery production (10.2\%), followed by food and kindred products distribution $(4.9 \%)$ and forest product manufacturing $(3.0 \%)$. Other industry groups showed little growth or declined slightly during this period. The solid long-term growth for the 


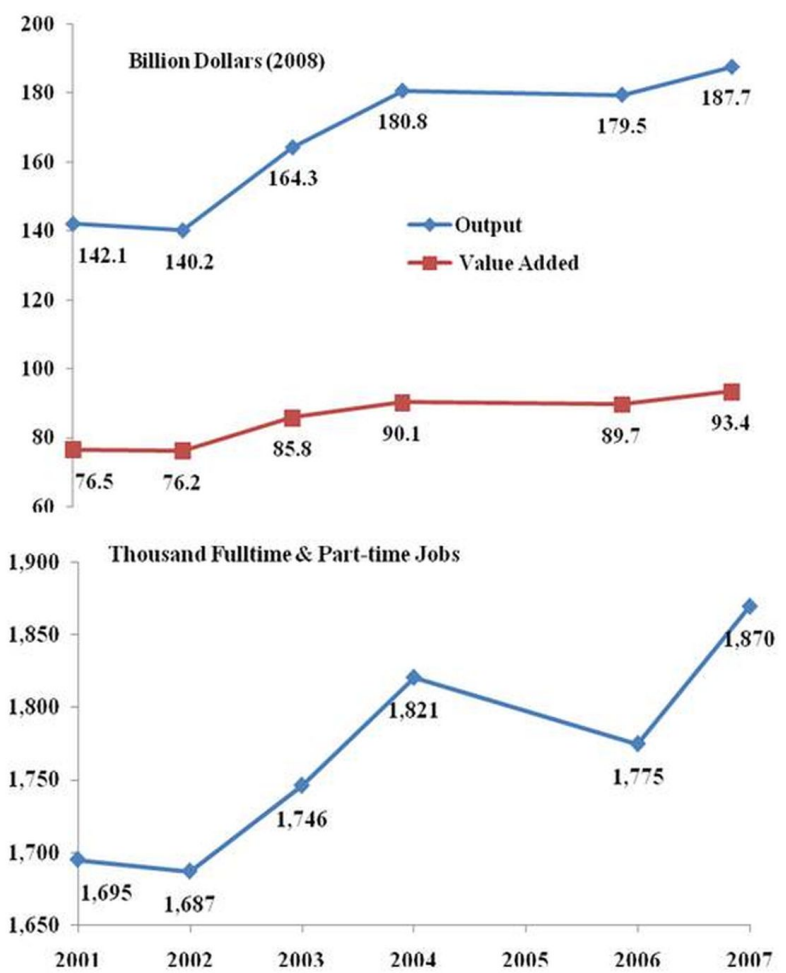

Figure 10. Trends in economic impacts during 2001-2007 for Florida agricultural, natural resource, and food and kindred product manufacturing, distribution, and service industries.

crop, livestock, forestry and fishery production sectors continued in 2007, with an 11.6 percent increase, while the high growth for mining was primarily due to a significant increase $(72 \%)$ during 2006-07 alone (Table 4 and Figure 11).

Table 5 shows the trends for all economic impact measures for commodity groups during the 2001 to 2007 period, and the corresponding average annual percentage changes. Environmental horticulture (nursery and greenhouse, and landscape services) had a long-term annual growth in value-added impacts of 9.4 percent, but slowed in 2006-07 to 4.6 percent. Forestry, wood, and paper products manufacturing had a long-term growth of 5.4 percent annually, but declined by -6.7 percent during the latter part of the period. Commodity groups with growing value-added impacts for 2006-07 included fruit and vegetable farming and processing (4.2\%); sugarcane farming, refined sugar, and confections (4.2\%); and grain and oilseed farming and processing (20.1\%).

Value-added impacts decreased for livestock and
Value Added Impacts by Industry Group, 2001-0

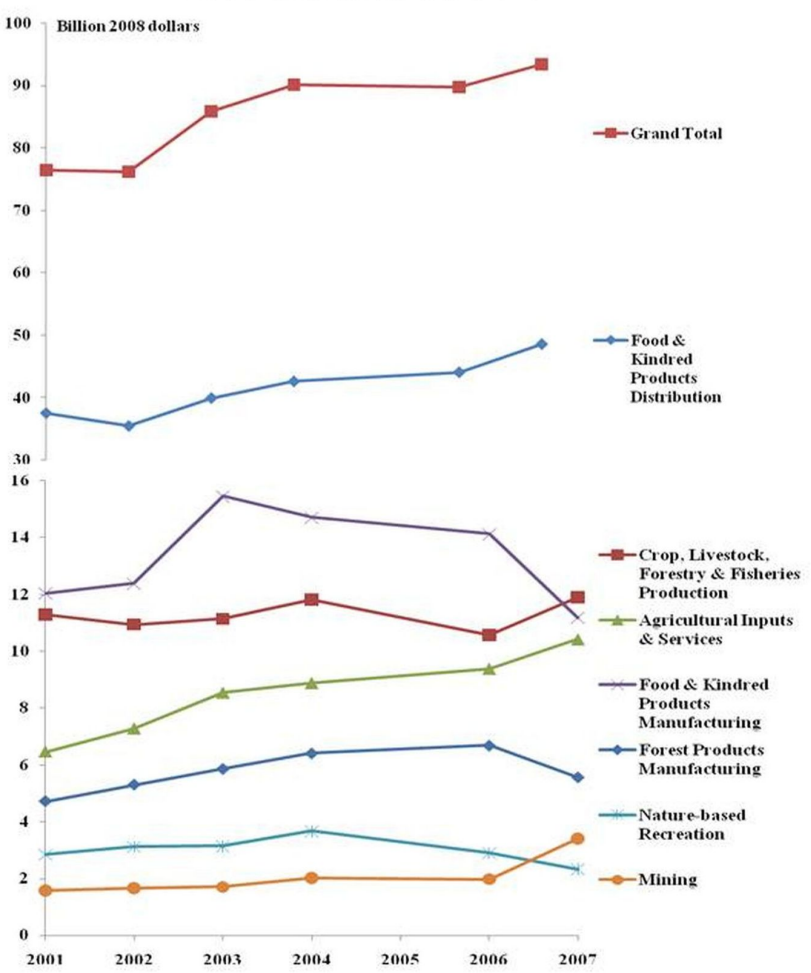

Figure 11. Trends in value-added impacts during 2001-2007 for industry groups in Florida agricultural, natural resource, and food and kindred product manufacturing, distribution, and services.

dairy farming, and animal products manufacturing $(-4.3 \%)$, and fishing and seafood products $(-7.7 \%)$.

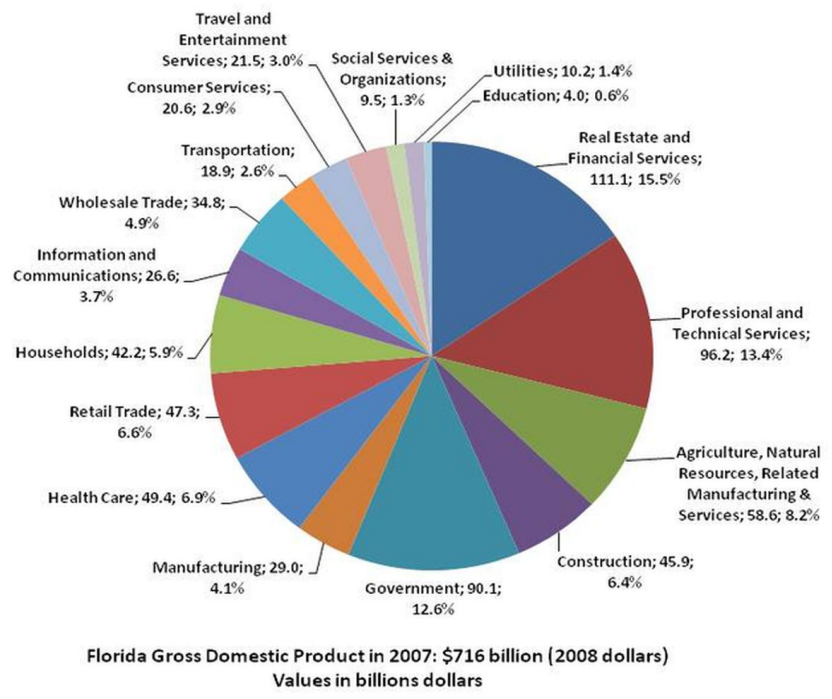

Figure 12. Contribution to Gross State Product (GSP) of Florida by major industry groups in 2007.

Individual industry sectors with significant increases in value-added impacts between 2001 and 2007 included food services and drinking places 
(\$8.3 Bn, 7.5\% annually), and landscape services (\$1.6 Bn, 10.7\% annually). Wholesale trade food and kindred products increased over the long term $(\$ 1.9$ Bn, 3.0\% annually), but decreased during 2006-07. Other industry sectors that had increased value-added impacts over the long term were extraction of oil and natural gas ( $\$ 1.0 \mathrm{Bn}, 79.6 \%$ annually), of which most was in 2007 (\$690 Mn); fertilizer manufacturing ( $\$ 938 \mathrm{Mn}, 7.0 \%$ annually), again mostly in 2007 (\$516 Mn); fruit farming (\$896 Mn, $8.8 \%$ annually), with significant growth of more than $\$ 1.0 \mathrm{Bn}$ in 2007; and veterinary (\$882 Mn, 20.7\% annually), including \$516 Mn during the latter part of the period. Individual industry sectors that showed a decline in value-added impacts included tobacco product manufacturing, which had a substantial growth of $\$ 1.7 \mathrm{Bn}$ between 2001 and 2006, but declined by more than $\$ 1.0$ Bn during 2006-07; frozen food manufacturing ( $\$ 883 \mathrm{Mn}$ ), of which -\$464 Mn was during 2006-2007; golf courses $(-\$ 602 \mathrm{Mn})$; support activities for agriculture and forestry ( $-\$ 529 \mathrm{Mn})$; bread and bakery products manufacturing ( $-\$ 372 \mathrm{Mn})$; fruit/vegetable canning/drying (-\$348 Mn); and pulp mills ( $\$ 336$ $\mathrm{Mn})$.

\section{Share of Gross State Product and Employment}

The relative importance of the agriculture, natural resources, and related food and service industries in Florida can be gauged by its share of overall economic activity in the state. The Gross State Product (GSP) of Florida in 2007 was \$716 Bn (2008 U.S. dollars), which is equivalent to the sum of value added by all industries. Total employment in the state was 10.3 million jobs. The direct value added contributed by agriculture, natural resources, and related food and service industries (\$58.62 Bn) represented 8.2 percent of Florida's GSP.

Agriculture, natural resources and related food and service industries ranked fourth among major industry groups (Figure 12). Direct employment in these industries represented 13.3 percent of all jobs in the state; these industries ranked second among major industry groups, behind professional and technical services (Figure 13). Excluding food and kindred products distribution, the agriculture, natural resources, and related industries represented 3.0 percent of Florida's GSP and 4.1 percent of Florida's total state employment. Note that some industry sectors in this analysis were reclassified from their original designation under the North American Industry Classification System (NAICS) to be included as part of the broadly defined agriculture and related industries.

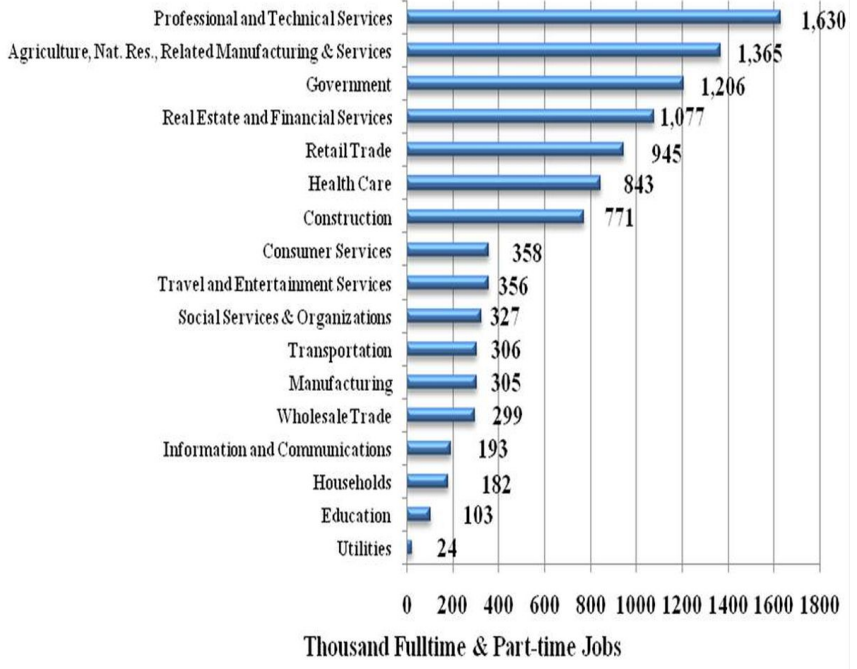

Figure 13. Direct employment by major industry groups in Florida in 2007.

\section{Conclusions}

This analysis shows that agriculture and natural resources are linked to a broad array of economic sectors for commodity production, and food and kindred product manufacturing, distribution, and related service activities. These industries collectively have a significant economic impact on the Florida economy, accounting for about 8.2 percent of Florida's GSP and 13.3 percent of Florida's total employment, which is ranked second among major industry groups. Food and kindred products distribution is by far the largest segment of the industry, representing 52 percent of value-added impacts and 59 percent of employment impacts. These industries are present throughout the state, with major activity in urbanized metropolitan areas, as well as rural counties, where it may be relatively more important as a share of total economic activity, although less in absolute magnitude. The industries have grown substantially since 2001 ; however, growth significantly slowed during 2006-07, along with the overall Florida and U.S. economies. 
In addition to these estimates of commercial activity and employment, agricultural and forest lands provide valuable non-marketed environmental services for water supply, water quality improvement, pollution abatement, erosion control and shoreline protection, carbon sequestration and climate stabilization, wildlife habitat, and open space for community buffers and outdoor recreation. These non-market values, however, are beyond the scope of this analysis.

\section{References}

Hodges, Alan W. and John J. Haydu. 2006. Economic Impacts of the Florida Environmental Horticulture Industry in 2005. Electronic Data Information Source (EDIS) FE675. University of Florida, Gainesville FL. http://edis.ifas.ufl.edu/FE675

Hodges, Alan W. and John J. Haydu. 2002. Economic Impacts of the Florida Golf Course Industry. Economic Information Report EIR 02-04. Food and Resource Economics Department, University of Florida, Gainesville, FL (June). Executive summary available at http://edis.ifas.ufl.edu/pdffiles/FE/FE34400.pdf

Hodges, Alan W., W. David Mulkey, Janaki R. Alavalapati, and Douglas R. Carter. 2006. Economic Impacts of the Forest Industry in Florida, 2003. Electronic Data Information Source (EDIS) FE538. University of Florida, Gainesville FL. http://edis.ifas.ufl.edu/FE538

Hodges, Alan W., M. Rahmani, and W. David Mulkey. Economic Impacts of the Florida Citrus Industry in 2003-04. 2005. Electronic Data Information Source (EDIS) FE633. University of Florida, Gainesville, FL. http://edis.ifas.ufl.edu/FE633

Hodges, Alan W., M. Rahmani, and W. David Mulkey. 2008. Economic Contributions of Agricultural, Food Manufacturing and Natural Resource Industries in Florida in 2006. Electronic Data Information Source (EDIS) FE702. University of Florida, Gainesville FL. http://edis.ifas.ufl.edu/FE702
Johnson, K. and J. Kort. 2004. Redefinition of the BEA Economic Areas. In Survey of Current Business. Washington, D.C.: Bureau of Economic Analysis, United States Department of Commerce. http://www.bea.gov/scb/pdf/2004/11November/ 1104Econ-Areas.pdf

Miller, R. E. and P.D. Blair. 1985. Input-Output Analysis: Foundations and Extensions. Prentice-Hall, Englewood Cliffs, NJ: Prentice-Hall Publishers (Second revised edition by Cambridge University Press to be published May 2009).

Minnesota IMPLAN Group, Inc. (MIG). IMPLAN System (data and software). Stillwater, $\mathrm{MN}$. Web resources available at http://www.implan.com

USDA/BEA. 2008. Gross Domestic Product Implicit Price Deflator, 1970-2008. United States Department of Commerce, Bureau of Economic Analysis, Washington, D.C.

http://research.stlouisfed.org/fred2/data/GDPDEF.txt

Watson, P., J. Wilson, D. Thilmany, and S. Winter. 2007. Determining economic contributions and impacts: What is the difference and why do we care? Journal of Regional Analysis and Policy 37 (2): 140-146.

http://www.jrap-journal.org/pastvolumes/2000/v37/ $\underline{\text { F37-2-6.pdf }}$

\section{Appendix: Glossary of Economic Impact Terms}

(Terms are presented in a logical order, rather than alphabetical order.)

Region defines the geographic area for which impacts are estimated. Regions are generally an aggregation of one or more counties. Economic regions identified in this document were defined based on work commuting patterns.

Sector is a grouping of industries that produce similar products or services, or production processes. Most economic reporting and models in the United States are based on the Standard Industrial Classification system (SIC code) or the the North American Industrial Classification System (NAICS). 
Impact analysis estimates the impact of a change in output or employment resulting from a change in final demand to households, governments, or exports.

Input-output (I-O model is a representation of the flows of economic activity between industry sectors within a region. The model captures what each business or sector must purchase from every other sector in order to produce its output of goods or services. Using such a model, flows of economic activity associated with any change in spending may be traced backwards (e.g., purchases of plants that lead growers to purchase additional inputs-fertilizers, containers, etc.). Multipliers for a region may be derived form an input-output model of the region's economy.

IMPLAN is a microcomputer-based input-output modeling system and social accounting matrix (SAM). With IMPLAN, one can estimate I-O models of up to 440 sectors for any region consisting of one or more counties. IMPLAN includes procedures for generating multipliers and estimating impacts by applying final demand changes to the model. The current version of the software is IMPLAN Pro 2.

Direct effects are the changes in economic activity during the first round of spending. Secondary effects are the changes in economic activity from subsequent rounds of re-spending. There are two types of secondary effects: indirect and induced. Indirect effects are the changes in sales, income, or employment within the region in backward-linked industries supplying goods and services to businesses (e.g., the increased sales in input supply firms resulting from more nursery industry sales). Induced effects are the increased sales within the region from household spending of the income earned in the direct and supporting industries. Employees in the direct and supporting industries spend the income they earn on housing, utilities, groceries, and other consumer goods and services. This generates sales, income, and employment throughout the region's economy. Total effects are the sum of direct, indirect, and induced effects.
Multipliers capture the total effects, both direct and secondary, in a given region, generally as a ratio of the total change in economic activity in the region relative to the direct change. Multipliers may be expressed as ratios of sales, income, or employment, or as ratios of total income or employment changes relative to direct sales. Multipliers express the degree of interdependency between sectors in a region's economy and therefore vary considerably across regions and sectors. Type I multipliers include only direct and indirect effects. Type II multipliers also include induced effects. Type SAM multipliers used by IMPLAN additionally account for capital investments and transfer payments such as welfare and retirement income. A sector-specific multiplier gives the total changes to the economy associated with a unit change in output or employment in a given sector.

Purchaser prices are the prices paid by the final consumer of a good or service. Producer prices are the prices of goods at the factory or production point. For manufactured goods, the purchaser price equals the producer price plus a retail margin, a wholesale margin, and a transportation margin. For services, the producer and purchaser prices are equivalent.

Margins. The retail, wholesale, and transportation margins are the portions of the purchaser price accruing to the retailer, wholesaler, and grower, respectively. Only the retail margins of many goods purchased by consumers accrue to the local region, as the wholesaler, shipper, and/or manufacturer often lie outside the local area.

Sales or output is the dollar volume of a good or service produced or sold. Final demand is sales to final consumers, including households and governments, and exporters. Intermediate sales are sales to other industrial sectors. Income is the money earned within the region from production and sales. Total income includes personal income (wage and salary income, including income from sole proprietor profits and rents). Jobs or employment is a measure of the number of jobs required to produce a given volume of sales/production, usually expressed as full-time equivalents, or as the total number (includes full-time, part-time and seasonal positions). Value added is the sum of total income and indirect 
business taxes. Value added is the most commonly used measure of the contribution of a region to the national economy since it avoids double counting of intermediate sales and captures only the value added by the region to final products. 
Table 1. Economic contributions of Florida agricultural, natural resource, and food and kindred product manufacturing, distribution, and service industry groups and sectors in 2007.

\begin{tabular}{|c|c|c|c|c|c|c|c|}
\hline $\begin{array}{l}\text { Industry Group / } \\
\text { Sector }\end{array}$ & $\begin{array}{l}\text { Industry } \\
\text { Output }\end{array}$ & $\begin{array}{r}\text { Foreign } \\
\text { and } \\
\text { Domestic } \\
\text { Exports }\end{array}$ & $\begin{array}{r}\text { Total } \\
\text { Output } \\
\text { Impacts }\end{array}$ & $\begin{array}{l}\text { Direct } \\
\text { Value } \\
\text { Added }\end{array}$ & $\begin{array}{l}\text { Value } \\
\text { Added } \\
\text { Impacts }\end{array}$ & $\begin{array}{c}\text { Direct } \\
\text { Employment }\end{array}$ & $\begin{array}{l}\text { Employment } \\
\text { Impacts }\end{array}$ \\
\hline & \multicolumn{5}{|c|}{ (2008 U.S. million dollars) } & \multicolumn{2}{|c|}{ (full-time and part-time jobs) } \\
\hline $\begin{array}{l}\text { Crop, Livestock, } \\
\text { Forestry \& Fisheries } \\
\text { Production }\end{array}$ & 11,299 & 6,523 & 20,229 & 6,482 & 11,903 & 172,482 & 264,964 \\
\hline Fruit farming & 2,245 & 1,618 & 4,472 & 1,217 & 2,587 & 24,751 & 50,189 \\
\hline $\begin{array}{l}\text { Greenhouse, } \\
\text { nursery, and } \\
\text { floriculture } \\
\text { production }\end{array}$ & 2,033 & 1,327 & 3,860 & 1,438 & 2,546 & 19,128 & 36,223 \\
\hline $\begin{array}{l}\text { Vegetable and } \\
\text { melon farming }\end{array}$ & 1,703 & 1,021 & 3,077 & 906 & 1,746 & 10,938 & 25,288 \\
\hline $\begin{array}{l}\text { Support activities } \\
\text { for agriculture and } \\
\text { forestry }\end{array}$ & 1,467 & 922 & 2,829 & 1,218 & 2,030 & 74,484 & 86,054 \\
\hline $\begin{array}{l}\text { Cattle ranching } \\
\text { and farming }\end{array}$ & 931 & 304 & 1,254 & 274 & 453 & 8,134 & 11,069 \\
\hline $\begin{array}{l}\text { Commercial } \\
\text { logging }\end{array}$ & 734 & 111 & 880 & 416 & 503 & 3,416 & 4,649 \\
\hline $\begin{array}{l}\text { Forestry, forest } \\
\text { products, and } \\
\text { timber tract } \\
\text { production }\end{array}$ & 652 & 652 & 1,610 & 391 & 991 & 1,368 & 14,062 \\
\hline $\begin{array}{l}\text { Sugarcane and } \\
\text { sugar beet } \\
\text { farming }\end{array}$ & 456 & 173 & 694 & 206 & 351 & 13,671 & 16,150 \\
\hline $\begin{array}{l}\text { Poultry and egg } \\
\text { production }\end{array}$ & 376 & 169 & 562 & 68 & 171 & 812 & 2,546 \\
\hline $\begin{array}{l}\text { Animal production, } \\
\text { excluding cattle, } \\
\text { poultry, and eggs }\end{array}$ & 247 & 13 & 265 & 132 & 143 & 6,033 & 6,204 \\
\hline $\begin{array}{l}\text { All other crop } \\
\text { farming }\end{array}$ & 217 & 127 & 378 & 66 & 166 & 1,271 & 2,979 \\
\hline Commercial fishing & 164 & 22 & 193 & 121 & 139 & 7,691 & 7,946 \\
\hline Cotton farming & 40 & 38 & 92 & 20 & 51 & 228 & 742 \\
\hline Grain farming & 14 & 10 & 27 & 5 & 12 & 265 & 392 \\
\hline Tobacco farming & 14 & 10 & 26 & 2 & 10 & 254 & 389 \\
\hline Tree nut farming & 2 & 1 & 4 & 1 & 2 & 16 & 37 \\
\hline Oilseed farming & 2 & 2 & 4 & 1 & 2 & 23 & 46 \\
\hline
\end{tabular}


Table 1. Economic contributions of Florida agricultural, natural resource, and food and kindred product manufacturing, distribution, and service industry groups and sectors in 2007.

\begin{tabular}{|c|c|c|c|c|c|c|c|}
\hline $\begin{array}{l}\text { Industry Group / } \\
\text { Sector }\end{array}$ & $\begin{array}{l}\text { Industry } \\
\text { Output }\end{array}$ & $\begin{array}{r}\text { Foreign } \\
\text { and } \\
\text { Domestic } \\
\text { Exports }\end{array}$ & $\begin{array}{r}\text { Total } \\
\text { Output } \\
\text { Impacts }\end{array}$ & $\begin{array}{l}\text { Direct } \\
\text { Value } \\
\text { Added }\end{array}$ & $\begin{array}{l}\text { Value } \\
\text { Added } \\
\text { Impacts }\end{array}$ & $\begin{array}{c}\text { Direct } \\
\text { Employment }\end{array}$ & $\begin{array}{r}\text { Employment } \\
\text { Impacts }\end{array}$ \\
\hline & \multicolumn{5}{|c|}{ (2008 U.S. million dollars) } & \multicolumn{2}{|c|}{ (full-time and part-time jobs) } \\
\hline $\begin{array}{l}\text { Agricultural Inputs } \\
\text { \& Services }\end{array}$ & 13,759 & 7,837 & 23,547 & 4,981 & 10,419 & 137,880 & 213,274 \\
\hline $\begin{array}{l}\text { Fertilizer } \\
\text { manufacturing }\end{array}$ & 5,085 & 4,096 & 9,796 & 744 & 3,180 & 5,022 & 37,753 \\
\hline $\begin{array}{l}\text { Landscape } \\
\text { services }\end{array}$ & 4,788 & 1,970 & 7,433 & 2,444 & 4,019 & 81,759 & 104,458 \\
\hline Veterinary services & 1,919 & 824 & 3,111 & 881 & 1,591 & 25,443 & 35,363 \\
\hline $\begin{array}{l}\text { Pest control } \\
\text { services }\end{array}$ & 1.466 & 603 & 2,275 & 748 & 1,230 & 25,028 & 31,977 \\
\hline $\begin{array}{l}\text { Pesticide and other } \\
\text { agricultural } \\
\text { chemical } \\
\text { manufacturing }\end{array}$ & 419 & 309 & 813 & 134 & 347 & 273 & 3,074 \\
\hline $\begin{array}{l}\text { Farm machinery } \\
\text { and equipment } \\
\text { manufacturing }\end{array}$ & 68 & 34 & 105 & 28 & 49 & 320 & 614 \\
\hline $\begin{array}{l}\text { Lawn and garden } \\
\text { equipment } \\
\text { manufacturing }\end{array}$ & 13 & 0 & 14 & 2 & 2 & 34 & 35 \\
\hline $\begin{array}{l}\text { Food \& Kindred } \\
\text { Products } \\
\text { Manufacturing }\end{array}$ & 23,034 & 10,629 & 34,637 & 4,757 & 11,167 & 42,437 & 135,200 \\
\hline $\begin{array}{l}\text { Soft drink and ice } \\
\text { manufacturing }\end{array}$ & 4,730 & 3,937 & 8,153 & 571 & 2,373 & 7,331 & 30,810 \\
\hline $\begin{array}{l}\text { Tobacco products } \\
\text { manufacturing }\end{array}$ & 4,332 & 679 & 5,143 & 1,472 & 1,948 & 2,224 & 8,560 \\
\hline $\begin{array}{l}\text { Fruit and vegetable } \\
\text { canning, pickling, } \\
\text { and drying }\end{array}$ & 2,394 & 2,084 & 4,680 & 476 & 1,761 & 3,358 & 20,986 \\
\hline $\begin{array}{l}\text { Sugar } \\
\text { manufacturing }\end{array}$ & 1,490 & 1,134 & 3,338 & 188 & 1,140 & 1,934 & 20,687 \\
\hline $\begin{array}{l}\text { Fluid milk and } \\
\text { butter } \\
\text { manufacturing }\end{array}$ & 1,174 & 11 & 1,189 & 147 & 155 & 1,870 & 1,988 \\
\hline $\begin{array}{l}\text { Bread and bakery } \\
\text { product } \\
\text { manufacturing }\end{array}$ & 1,122 & 29 & 1,160 & 306 & 328 & 7,425 & 7,736 \\
\hline
\end{tabular}


Table 1. Economic contributions of Florida agricultural, natural resource, and food and kindred product manufacturing, distribution, and service industry groups and sectors in 2007.

\begin{tabular}{|c|c|c|c|c|c|c|c|}
\hline $\begin{array}{l}\text { Industry Group / } \\
\text { Sector }\end{array}$ & $\begin{array}{l}\text { Industry } \\
\text { Output }\end{array}$ & $\begin{array}{r}\text { Foreign } \\
\text { and } \\
\text { Domestic } \\
\text { Exports }\end{array}$ & $\begin{array}{l}\text { Total } \\
\text { Output } \\
\text { Impacts }\end{array}$ & $\begin{array}{l}\text { Direct } \\
\text { Value } \\
\text { Added }\end{array}$ & $\begin{array}{l}\text { Value } \\
\text { Added } \\
\text { Impacts }\end{array}$ & $\begin{array}{c}\text { Direct } \\
\text { Employment }\end{array}$ & $\begin{array}{r}\text { Employment } \\
\text { Impacts }\end{array}$ \\
\hline & \multicolumn{5}{|c|}{ (2008 U.S. million dollars) } & \multicolumn{2}{|c|}{ (full-time and part-time jobs) } \\
\hline $\begin{array}{l}\text { Animal (excluding } \\
\text { poultry) } \\
\text { slaughtering, } \\
\text { rendering, and } \\
\text { processing }\end{array}$ & 1,061 & 94 & 1,162 & 105 & 156 & 2,381 & $\cdot 3,308$ \\
\hline Breweries & 992 & 763 & 1,854 & 303 & 811 & 961 & 7,854 \\
\hline $\begin{array}{l}\text { Seafood product } \\
\text { preparation and } \\
\text { packaging }\end{array}$ & 554 & 102 & 680 & 83 & 158 & 1,664 & 3,040 \\
\hline $\begin{array}{l}\text { Seasoning and } \\
\text { dressing } \\
\text { manufacturing }\end{array}$ & 539 & 23 & 563 & 72 & 85 & 1,198 & 1,372 \\
\hline Distilleries & 473 & 383 & 1,041 & 266 & 631 & 314 & 5,461 \\
\hline $\begin{array}{l}\text { Frozen food } \\
\text { manufacturing }\end{array}$ & 465 & 445 & 1,015 & 195 & 517 & 3,101 & 7,583 \\
\hline $\begin{array}{l}\text { Snack food } \\
\text { manufacturing }\end{array}$ & 447 & 47 & 497 & 80 & 108 & 705 & 1,084 \\
\hline $\begin{array}{l}\text { Poultry } \\
\text { processing }\end{array}$ & 442 & 28 & 472 & 76 & 91 & 1,976 & 2,192 \\
\hline $\begin{array}{l}\text { All other food } \\
\text { manufacturing }\end{array}$ & 391 & 67 & 478 & 63 & 114 & 1,454 & 2,164 \\
\hline $\begin{array}{l}\text { Coffee and tea } \\
\text { manufacturing }\end{array}$ & 372 & 37 & 423 & 66 & 96 & 622 & 1,054 \\
\hline $\begin{array}{l}\text { Other animal food } \\
\text { manufacturing }\end{array}$ & 337 & 303 & 547 & 27 & 146 & 454 & 2,020 \\
\hline $\begin{array}{l}\text { Cookie, cracker, } \\
\text { and pasta } \\
\text { manufacturing }\end{array}$ & 327 & 7 & 335 & 58 & 63 & 882 & 939 \\
\hline $\begin{array}{l}\text { Ice cream and } \\
\text { frozen dessert } \\
\text { manufacturing }\end{array}$ & 245 & 2 & 247 & 35 & 36 & 490 & 504 \\
\hline $\begin{array}{l}\text { Flavoring syrup } \\
\text { and concentrate } \\
\text { manufacturing }\end{array}$ & 234 & 3 & 236 & 32 & 34 & 86 & 103 \\
\hline $\begin{array}{l}\text { Non-chocolate } \\
\text { confectionery } \\
\text { manufacturing }\end{array}$ & 225 & 93 & 329 & 41 & 98 & 675 & 1,428 \\
\hline $\begin{array}{l}\text { Confectionery } \\
\text { manufacturing } \\
\text { from purchased } \\
\text { chocolate }\end{array}$ & 198 & 102 & 308 & 22 & 81 & 612 & 1,394 \\
\hline
\end{tabular}


Table 1. Economic contributions of Florida agricultural, natural resource, and food and kindred product manufacturing, distribution, and service industry groups and sectors in 2007.

\begin{tabular}{|c|c|c|c|c|c|c|c|}
\hline $\begin{array}{l}\text { Industry Group / } \\
\text { Sector }\end{array}$ & $\begin{array}{l}\text { Industry } \\
\text { Output }\end{array}$ & $\begin{array}{r}\text { Foreign } \\
\text { and } \\
\text { Domestic } \\
\text { Exports }\end{array}$ & $\begin{array}{r}\text { Total } \\
\text { Output } \\
\text { Impacts }\end{array}$ & $\begin{array}{l}\text { Direct } \\
\text { Value } \\
\text { Added }\end{array}$ & $\begin{array}{l}\text { Value } \\
\text { Added } \\
\text { Impacts }\end{array}$ & $\begin{array}{c}\text { Direct } \\
\text { Employment }\end{array}$ & $\begin{array}{l}\text { Employment } \\
\text { Impacts }\end{array}$ \\
\hline & \multicolumn{5}{|c|}{ (2008 U.S. million dollars) } & \multicolumn{2}{|c|}{ (full-time and part-time jobs) } \\
\hline $\begin{array}{l}\text { Flour milling and } \\
\text { malt } \\
\text { manufacturing }\end{array}$ & 163 & 136 & 338 & 28 & 130 & 177 & 1,472 \\
\hline $\begin{array}{l}\text { Dog and cat food } \\
\text { manufacturing }\end{array}$ & 116 & 64 & 171 & 16 & 46 & 112 & 518 \\
\hline Wineries & 66 & 30 & 107 & 12 & 36 & 175 & 498 \\
\hline $\begin{array}{l}\text { Chocolate and } \\
\text { confectionery from } \\
\text { cacao beans }\end{array}$ & 48 & 14 & 63 & 4 & 12 & 83 & 196 \\
\hline $\begin{array}{l}\text { Cheese } \\
\text { manufacturing }\end{array}$ & 47 & 1 & 48 & 5 & 6 & 59 & 65 \\
\hline $\begin{array}{l}\text { Dry, condensed, } \\
\text { and evaporated } \\
\text { dairy product } \\
\text { manufacturing }\end{array}$ & 25 & 6 & 31 & 2 & 6 & 30 & 83 \\
\hline $\begin{array}{l}\text { Fats and oils } \\
\text { refining and } \\
\text { blending }\end{array}$ & 16 & 4 & 18 & 1 & 2 & 12 & 26 \\
\hline $\begin{array}{l}\text { Tortilla } \\
\text { manufacturing }\end{array}$ & 12 & 0 & 12 & 3 & 3 & 72 & 72 \\
\hline $\begin{array}{l}\text { Forest Products } \\
\text { Manufacturing }\end{array}$ & 8,191 & 4,850 & 13,972 & 2,224 & 5,558 & 26,399 & 70,696 \\
\hline Paper mills & 1,614 & 1,586 & 3,825 & 379 & 1,646 & 2,221 & 18,800 \\
\hline $\begin{array}{l}\text { Sanitary paper } \\
\text { product } \\
\text { manufacturing }\end{array}$ & 1,157 & 695 & 1,801 & 288 & 658 & 1,643 & 6,611 \\
\hline $\begin{array}{l}\text { Paperboard } \\
\text { container } \\
\text { manufacturing }\end{array}$ & 1,142 & 1,134 & 2,219 & 258 & 894 & 3,285 & 11,857 \\
\hline $\begin{array}{l}\text { Wood windows } \\
\text { and doors and } \\
\text { millwork } \\
\text { manufacturing }\end{array}$ & 1,010 & 12 & 1,026 & 346 & 355 & 5,288 & 5,414 \\
\hline $\begin{array}{l}\text { Engineered wood } \\
\text { member and truss } \\
\text { manufacturing }\end{array}$ & 930 & 355 & 1,420 & 343 & 355 & 5,288 & 5,414 \\
\hline $\begin{array}{l}\text { Sawmills and wood } \\
\text { preservation }\end{array}$ & 743 & 57 & 832 & 178 & 229 & 2,700 & 3,354 \\
\hline Pulp mills & 401 & 401 & 1,005 & 90 & 433 & 558 & 5,053 \\
\hline $\begin{array}{l}\text { Stationery product } \\
\text { manufacturing }\end{array}$ & 320 & 307 & 647 & 76 & 270 & 1,038 & 3,639 \\
\hline
\end{tabular}


Table 1. Economic contributions of Florida agricultural, natural resource, and food and kindred product manufacturing, distribution, and service industry groups and sectors in 2007.

\begin{tabular}{|c|c|c|c|c|c|c|c|}
\hline $\begin{array}{l}\text { Industry Group / } \\
\text { Sector }\end{array}$ & $\begin{array}{l}\text { Industry } \\
\text { Output }\end{array}$ & $\begin{array}{r}\text { Foreign } \\
\text { and } \\
\text { Domestic } \\
\text { Exports }\end{array}$ & $\begin{array}{r}\text { Total } \\
\text { Output } \\
\text { Impacts }\end{array}$ & $\begin{array}{l}\text { Direct } \\
\text { Value } \\
\text { Added }\end{array}$ & $\begin{array}{l}\text { Value } \\
\text { Added } \\
\text { Impacts }\end{array}$ & $\begin{array}{r}\text { Direct } \\
\text { Employment }\end{array}$ & $\begin{array}{l}\text { Employment } \\
\text { Impacts }\end{array}$ \\
\hline & \multicolumn{5}{|c|}{ (2008 U.S. million dollars) } & \multicolumn{2}{|c|}{ (full-time and part-time jobs) } \\
\hline $\begin{array}{l}\text { Veneer and } \\
\text { plywood } \\
\text { manufacturing }\end{array}$ & 187 & 12 & 206 & 68 & 79 & 965 & 1,106 \\
\hline $\begin{array}{l}\text { Coated and } \\
\text { laminated paper } \\
\text { and packaging } \\
\text { manufacturing }\end{array}$ & 182 & 182 & 364 & 42 & 145 & 440 & 1,819 \\
\hline $\begin{array}{l}\text { Wood container } \\
\text { and pallet } \\
\text { manufacturing }\end{array}$ & 170 & 3 & 174 & 65 & 68 & 1,403 & 1,439 \\
\hline $\begin{array}{l}\text { All other paper bag } \\
\text { and coated and } \\
\text { treated paper } \\
\text { manufacturing }\end{array}$ & 132 & 15 & 146 & 30 & 38 & 394 & 508 \\
\hline $\begin{array}{l}\text { All other converted } \\
\text { paper product } \\
\text { manufacturing }\end{array}$ & 82 & 82 & 175 & 19 & 74 & 312 & 1,055 \\
\hline $\begin{array}{l}\text { All other } \\
\text { miscellaneous } \\
\text { wood product } \\
\text { manufacturing }\end{array}$ & 73 & 6 & 82 & 28 & 33 & 444 & 510 \\
\hline $\begin{array}{l}\text { Reconstituted } \\
\text { wood product } \\
\text { manufacturing }\end{array}$ & 47 & 2 & 49 & 15 & 16 & 160 & 177 \\
\hline Mining & 4,413 & 2,217 & 7,583 & 1,544 & 3,401 & 11,877 & 37,207 \\
\hline $\begin{array}{l}\text { Extraction of oil } \\
\text { and natural gas }\end{array}$ & 2,627 & 761 & 3,803 & 490 & 1,166 & 6,871 & 15,862 \\
\hline $\begin{array}{l}\text { Mining and } \\
\text { quarrying stone }\end{array}$ & 611 & 567 & 1,404 & 390 & 860 & 1,453 & 8,010 \\
\hline $\begin{array}{l}\text { Mining and } \\
\text { quarrying other } \\
\text { nonmetallic } \\
\text { minerals }\end{array}$ & 430 & 269 & 807 & 257 & 482 & 1,513 & 4,611 \\
\hline $\begin{array}{l}\text { Mining and } \\
\text { quarrying sand, } \\
\text { gravel, clay, and } \\
\text { ceramic and } \\
\text { refractory minerals }\end{array}$ & 265 & 265 & 626 & 154 & 368 & 1,157 & 4,115 \\
\hline $\begin{array}{l}\text { Drilling oil and gas } \\
\text { wells }\end{array}$ & 182 & 172 & 395 & 88 & 212 & 374 & 2,076 \\
\hline
\end{tabular}


Table 1. Economic contributions of Florida agricultural, natural resource, and food and kindred product manufacturing, distribution, and service industry groups and sectors in 2007.

\begin{tabular}{|c|c|c|c|c|c|c|c|}
\hline $\begin{array}{l}\text { Industry Group / } \\
\text { Sector }\end{array}$ & $\begin{array}{l}\text { Industry } \\
\text { Output }\end{array}$ & $\begin{array}{r}\text { Foreign } \\
\text { and } \\
\text { Domestic } \\
\text { Exports }\end{array}$ & $\begin{array}{l}\text { Total } \\
\text { Output } \\
\text { Impacts }\end{array}$ & $\begin{array}{l}\text { Direct } \\
\text { Value } \\
\text { Added }\end{array}$ & $\begin{array}{l}\text { Value } \\
\text { Added } \\
\text { Impacts }\end{array}$ & $\begin{array}{r}\text { Direct } \\
\text { Employment }\end{array}$ & $\begin{array}{l}\text { Employment } \\
\text { Impacts }\end{array}$ \\
\hline & \multicolumn{5}{|c|}{ (2008 U.S. million dollars) } & \multicolumn{2}{|c|}{ (full-time and part-time jobs) } \\
\hline $\begin{array}{l}\text { Mining gold, silver, } \\
\text { and other metal } \\
\text { ore }\end{array}$ & 92 & 17 & 115 & 60 & 74 & 66 & 249 \\
\hline $\begin{array}{l}\text { Mining copper, } \\
\text { nickel, lead, and } \\
\text { zinc }\end{array}$ & 70 & 31 & 117 & 47 & 76 & 75 & 460 \\
\hline Mining iron ore & 61 & 61 & 137 & 33 & 78 & 71 & 678 \\
\hline $\begin{array}{l}\text { Support activities } \\
\text { for oil and gas } \\
\text { operations }\end{array}$ & 55 & 55 & 134 & 20 & 66 & 248 & 883 \\
\hline $\begin{array}{l}\text { Support activities } \\
\text { for other mining }\end{array}$ & 19 & 19 & 45 & 6 & 21 & 49 & 265 \\
\hline $\begin{array}{l}\text { Nature-Based } \\
\text { Recreation }\end{array}$ & 1,970 & 1,071 & 3,667 & 1,301 & 2,322 & 26,929 & 41,724 \\
\hline Golf courses & 1,393 & 761 & 2,594 & 909 & 1,636 & 4,418 & 6,577 \\
\hline $\begin{array}{l}\text { Recreational } \\
\text { fishing }\end{array}$ & 290 & 158 & 540 & 189 & 341 & 1,302 & 3,575 \\
\hline $\begin{array}{l}\text { Commercial } \\
\text { hunting and } \\
\text { trapping }\end{array}$ & 287 & 152 & 532 & 202 & 345 & 21,209 & 31,571 \\
\hline $\begin{array}{l}\text { Subtotal, Excluding } \\
\text { Food \& Kindred } \\
\text { Products } \\
\text { Distribution }\end{array}$ & 62,666 & 33,127 & 103,634 & 21,387 & 44,771 & 418,003 & 763,064 \\
\hline $\begin{array}{l}\text { Food \& Kindred } \\
\text { Products } \\
\text { Distribution }\end{array}$ & 65,344 & 12,291 & 84,038 & 37,332 & 48,613 & 947,374 & $1,106,477$ \\
\hline $\begin{array}{l}\text { Food services and } \\
\text { drinking places }\end{array}$ & 39,339 & 7,684 & 50,472 & 20,077 & 26,724 & 653,894 & 746,925 \\
\hline $\begin{array}{l}\text { Wholesale trade, } \\
\text { food, and kindred } \\
\text { products }\end{array}$ & 13,389 & 3,559 & 19,227 & 8,696 & 12,268 & 74,727 & 125,708 \\
\hline $\begin{array}{l}\text { Retail stores (food } \\
\text { and beverages) }\end{array}$ & 11,194 & 927 & 12,718 & 7,565 & 8,505 & 202,339 & 215,695 \\
\hline $\begin{array}{l}\text { Retail lawn and } \\
\text { garden centers }\end{array}$ & 1,422 & 122 & 1,620 & 994 & 1,116 & 16,414 & 18,148 \\
\hline Grand Total & 128,010 & 45,418 & 187,672 & 58,619 & 93,384 & $1,365,377$ & $1,869,541$ \\
\hline $\begin{array}{l}\text { Source: IMPLAN Profe } \\
\text { Impact estimates inclu } \\
\text { Values expressed in } 2\end{array}$ & I data for & $\begin{array}{l}\text { la (MIG, } \\
\text { effects. }\end{array}$ & & & & 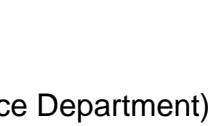 & \\
\hline
\end{tabular}




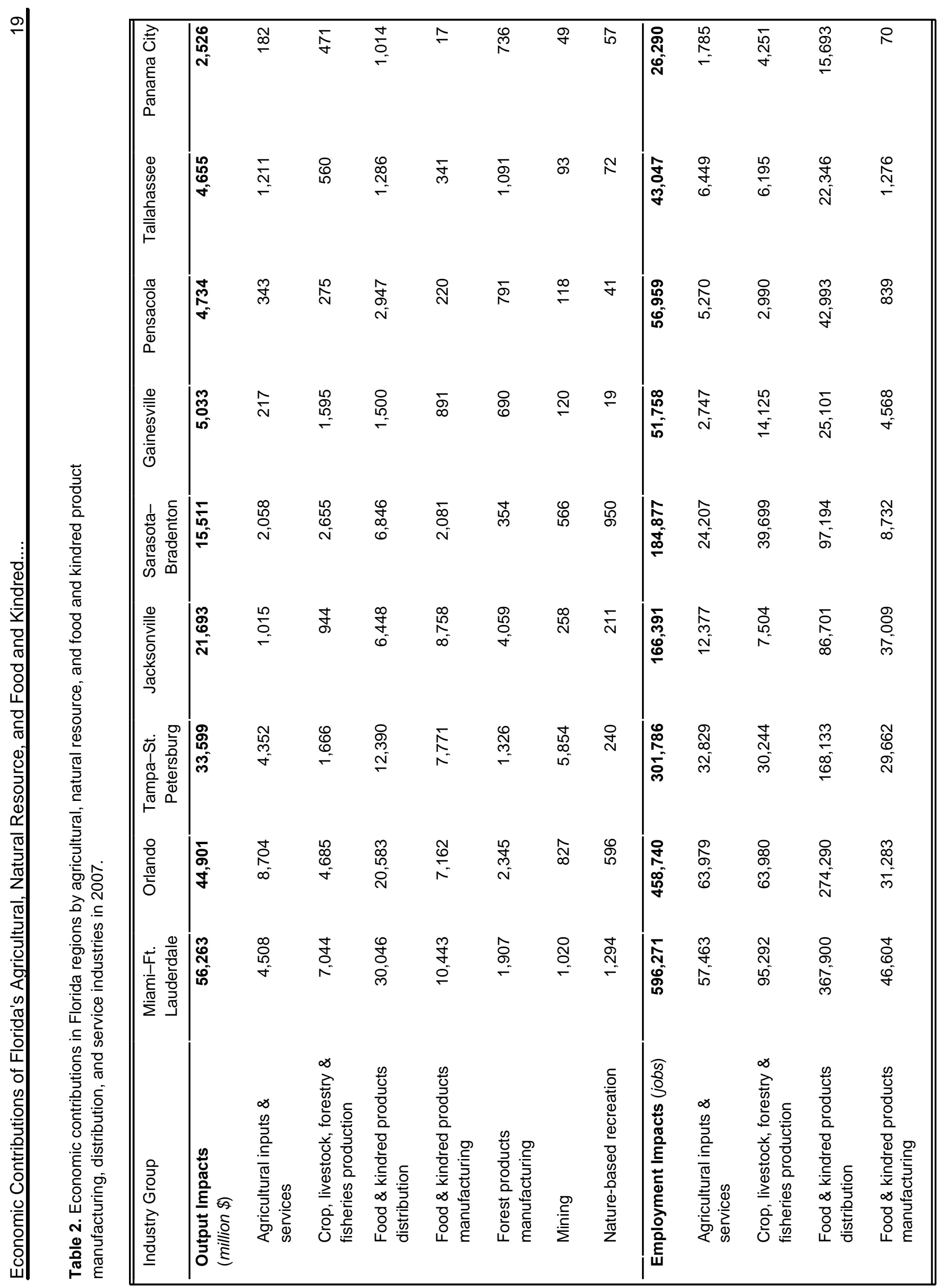




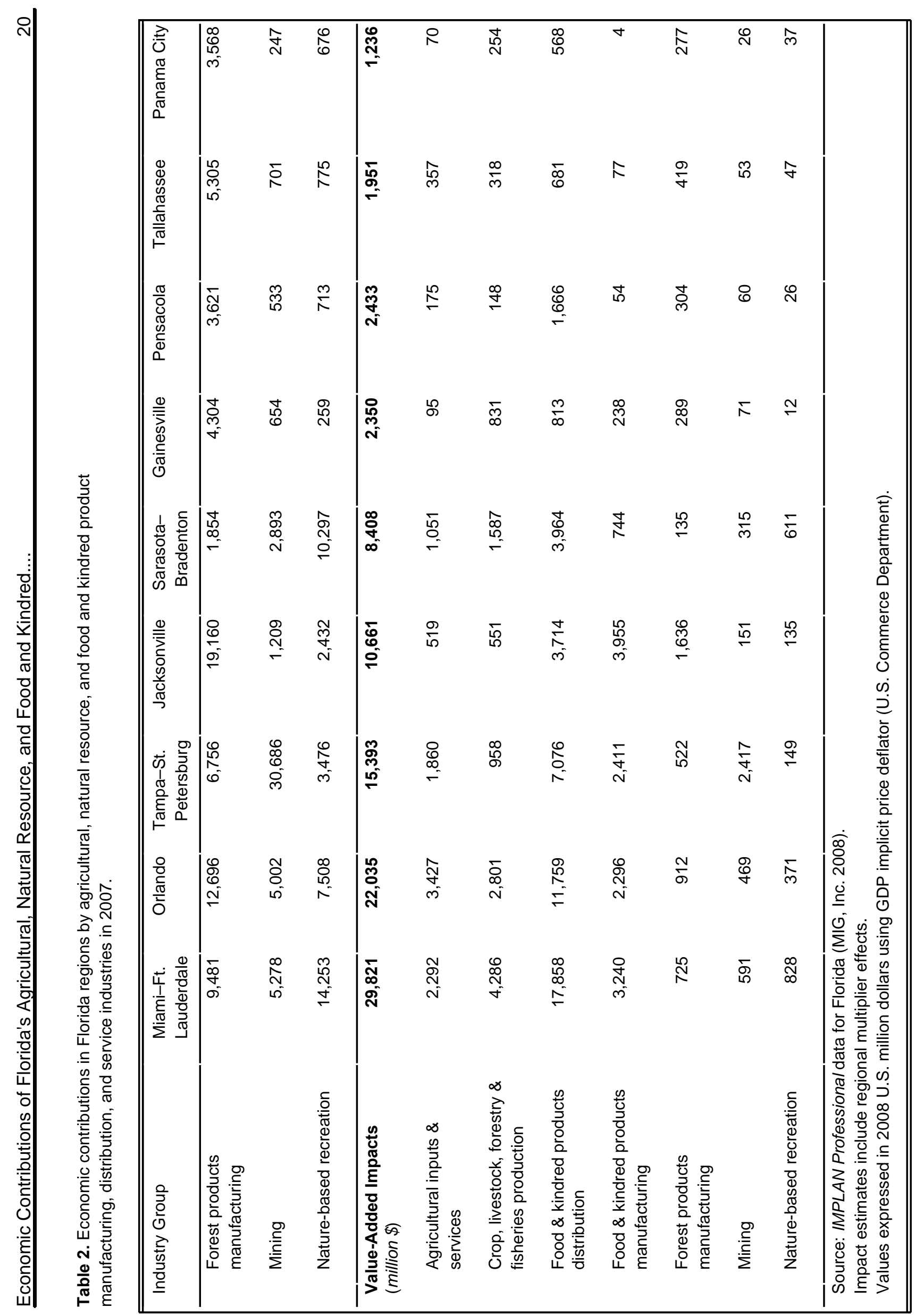




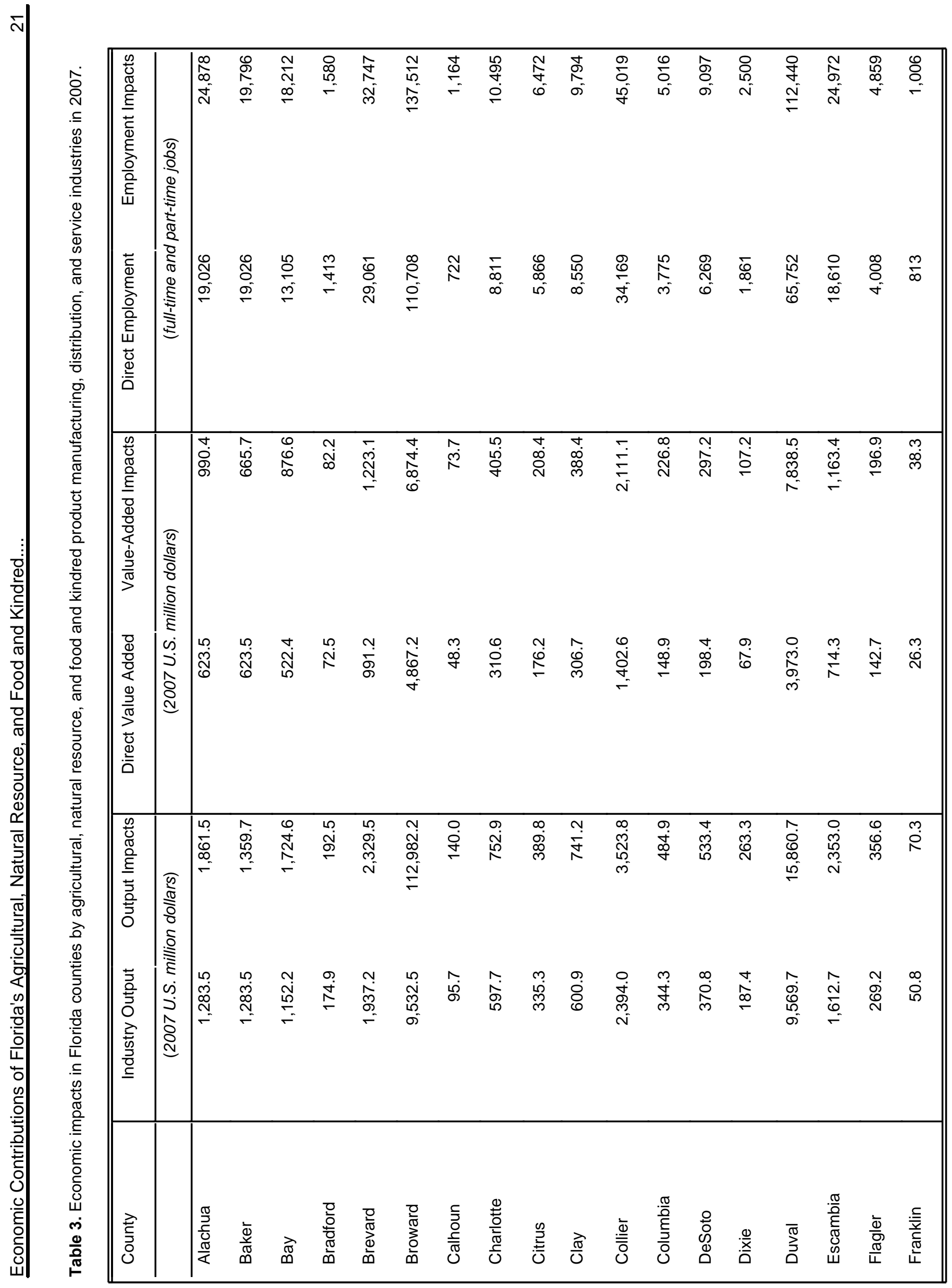




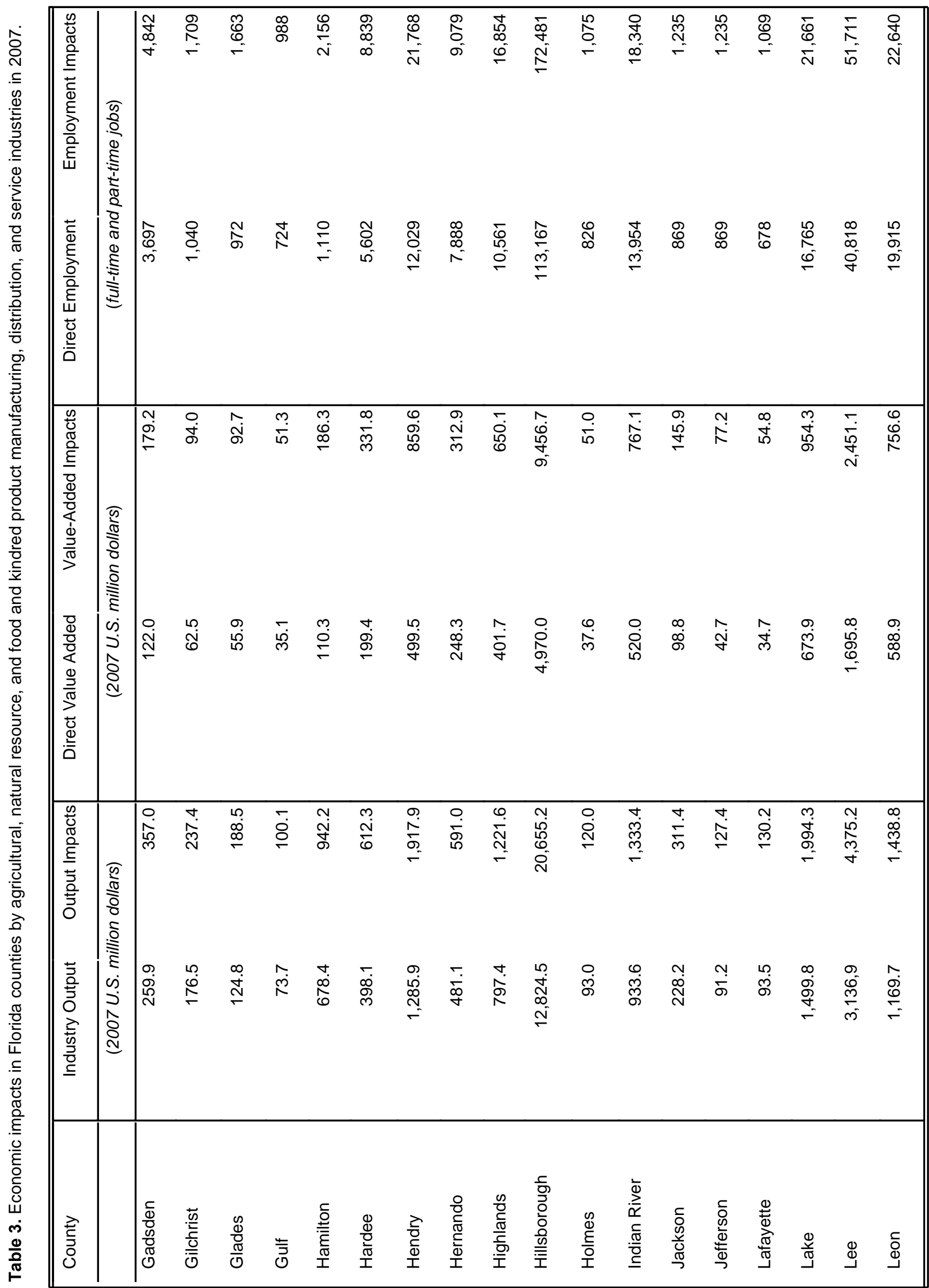




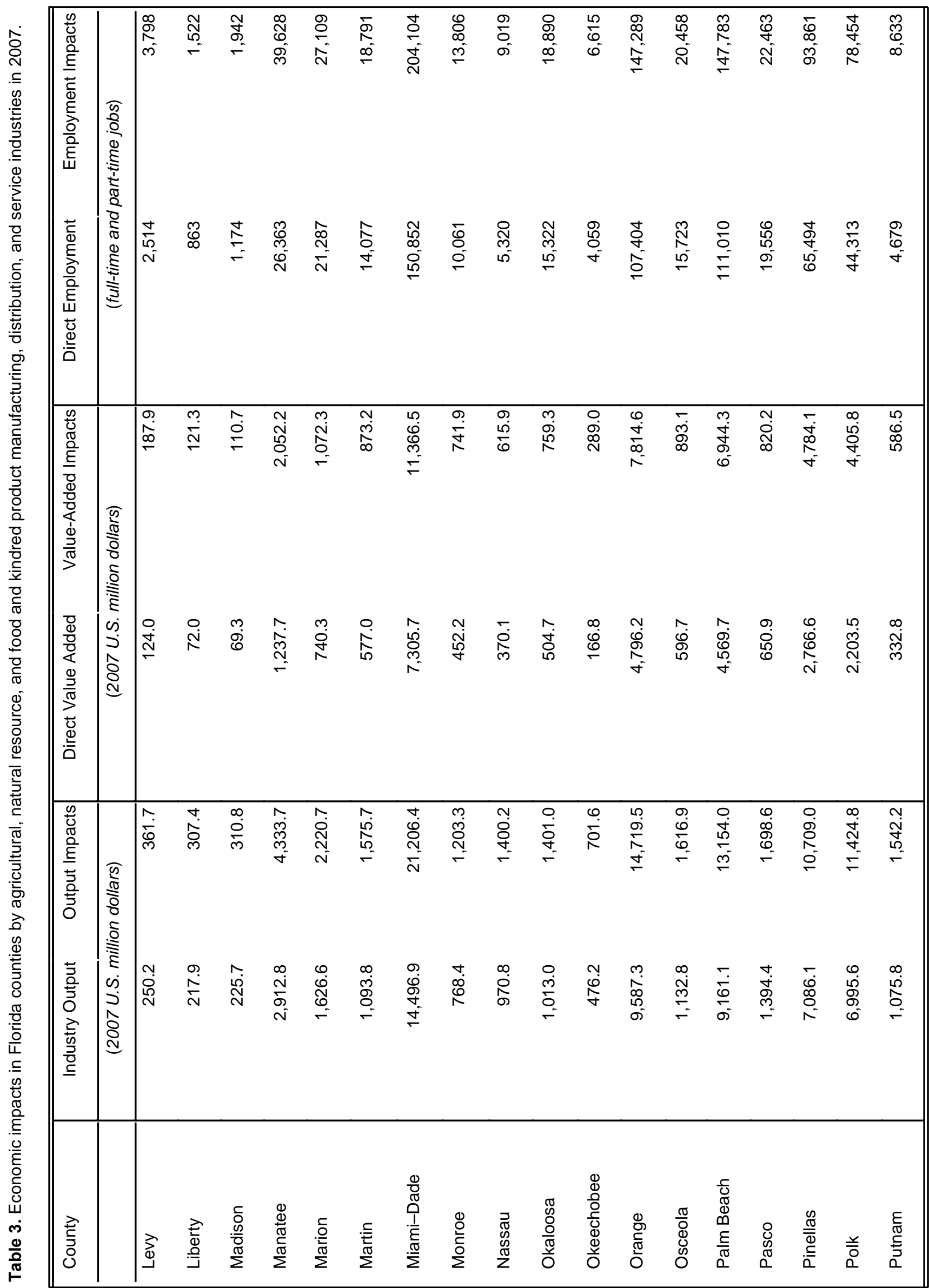




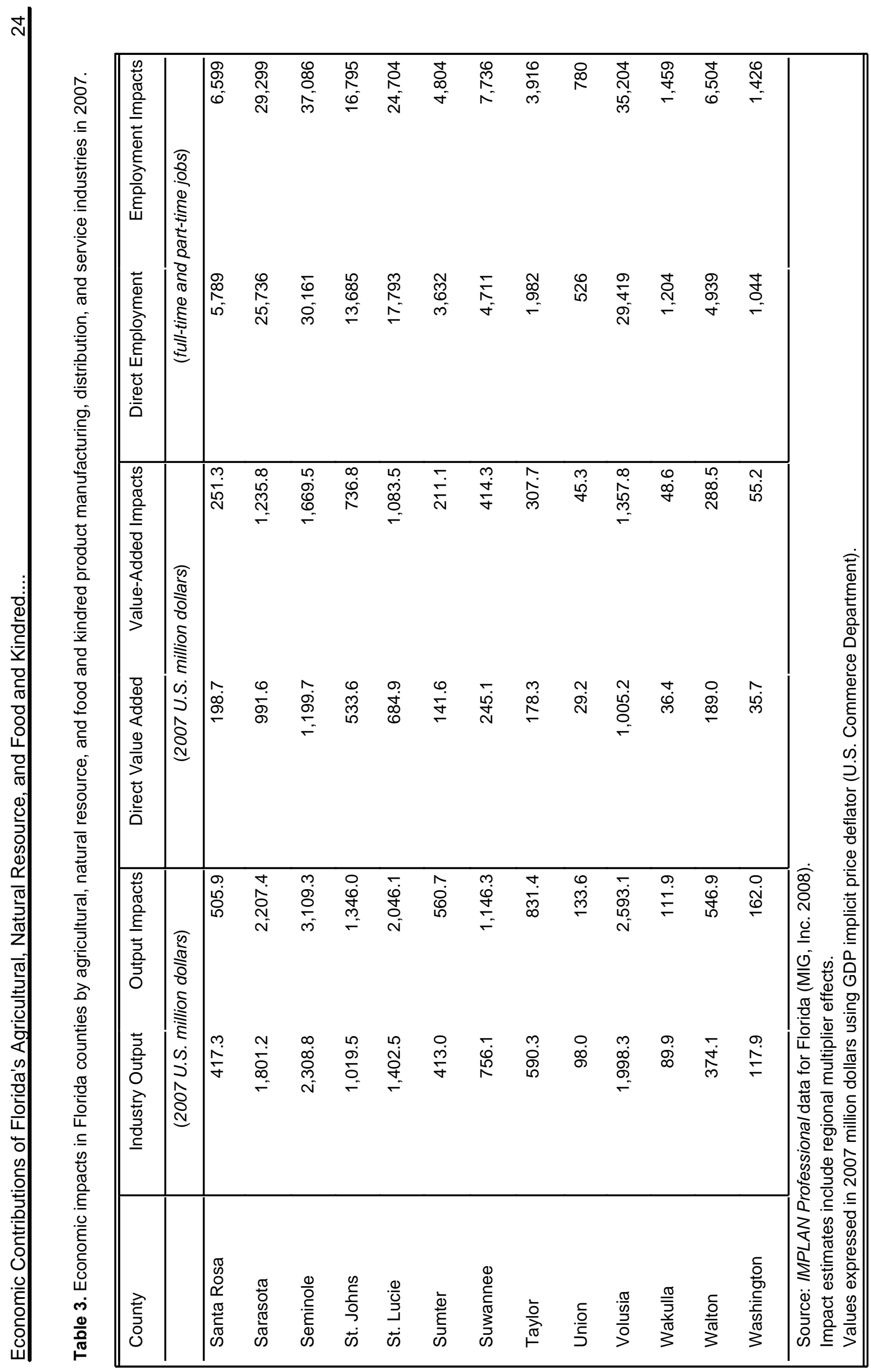




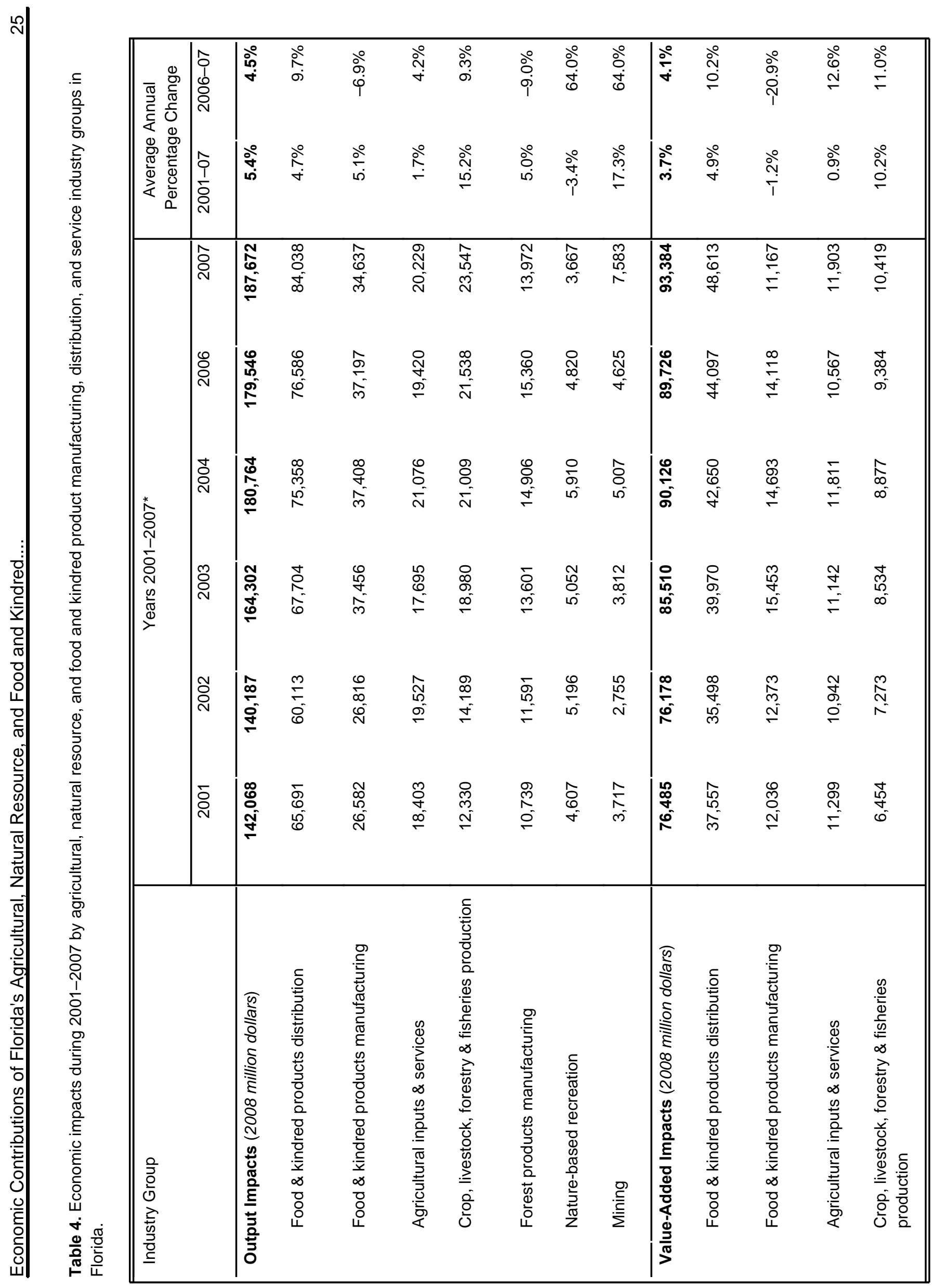




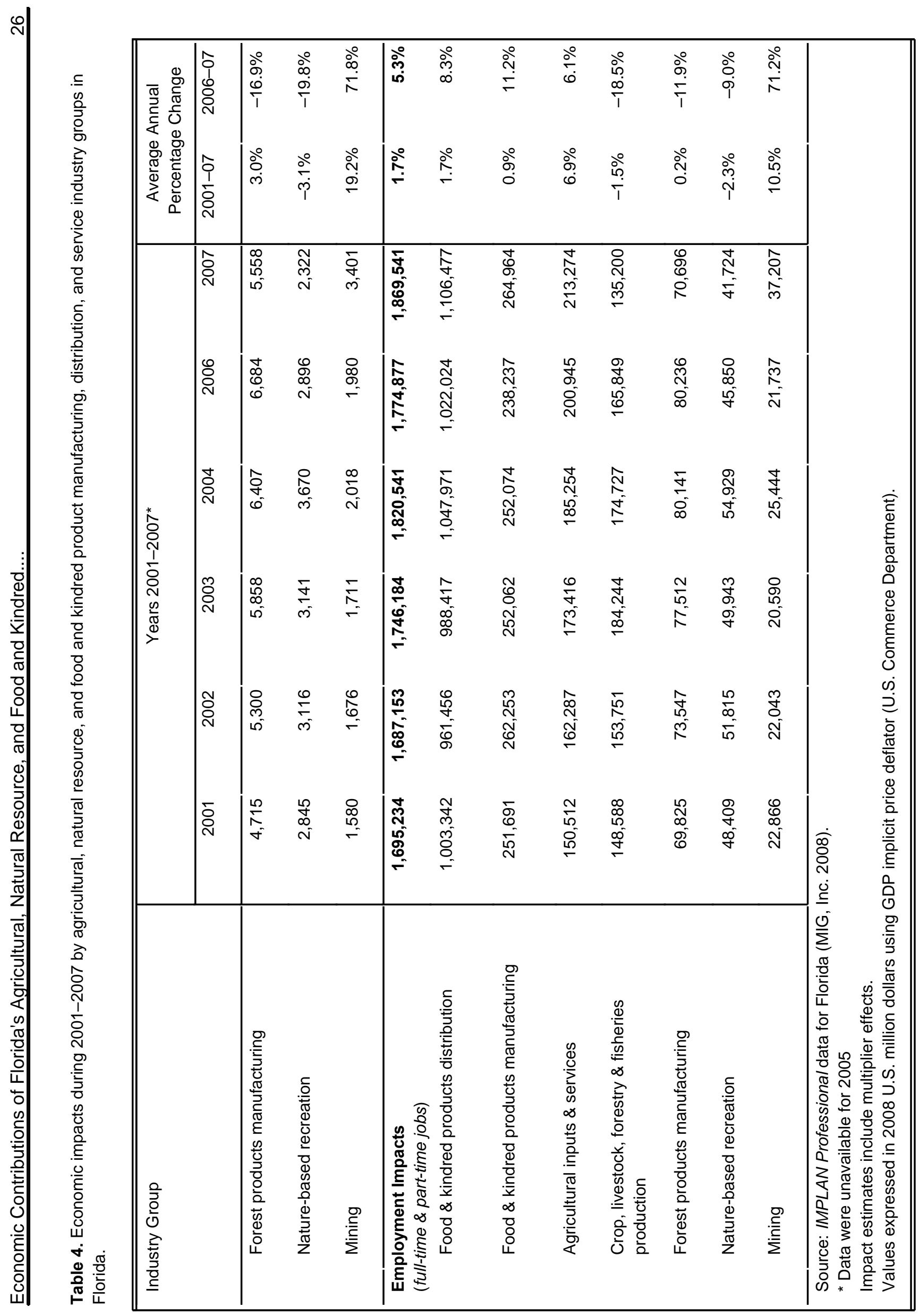




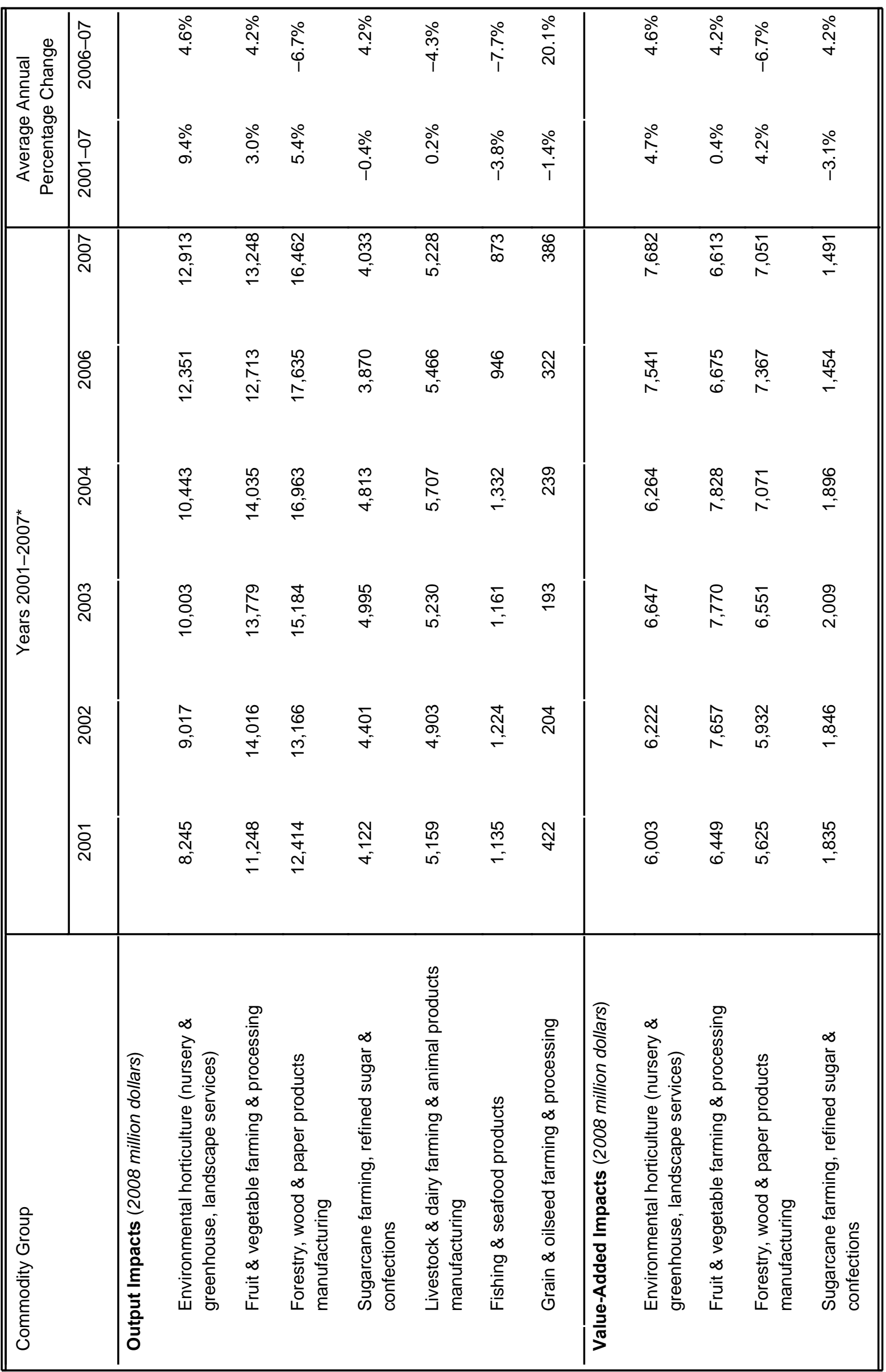




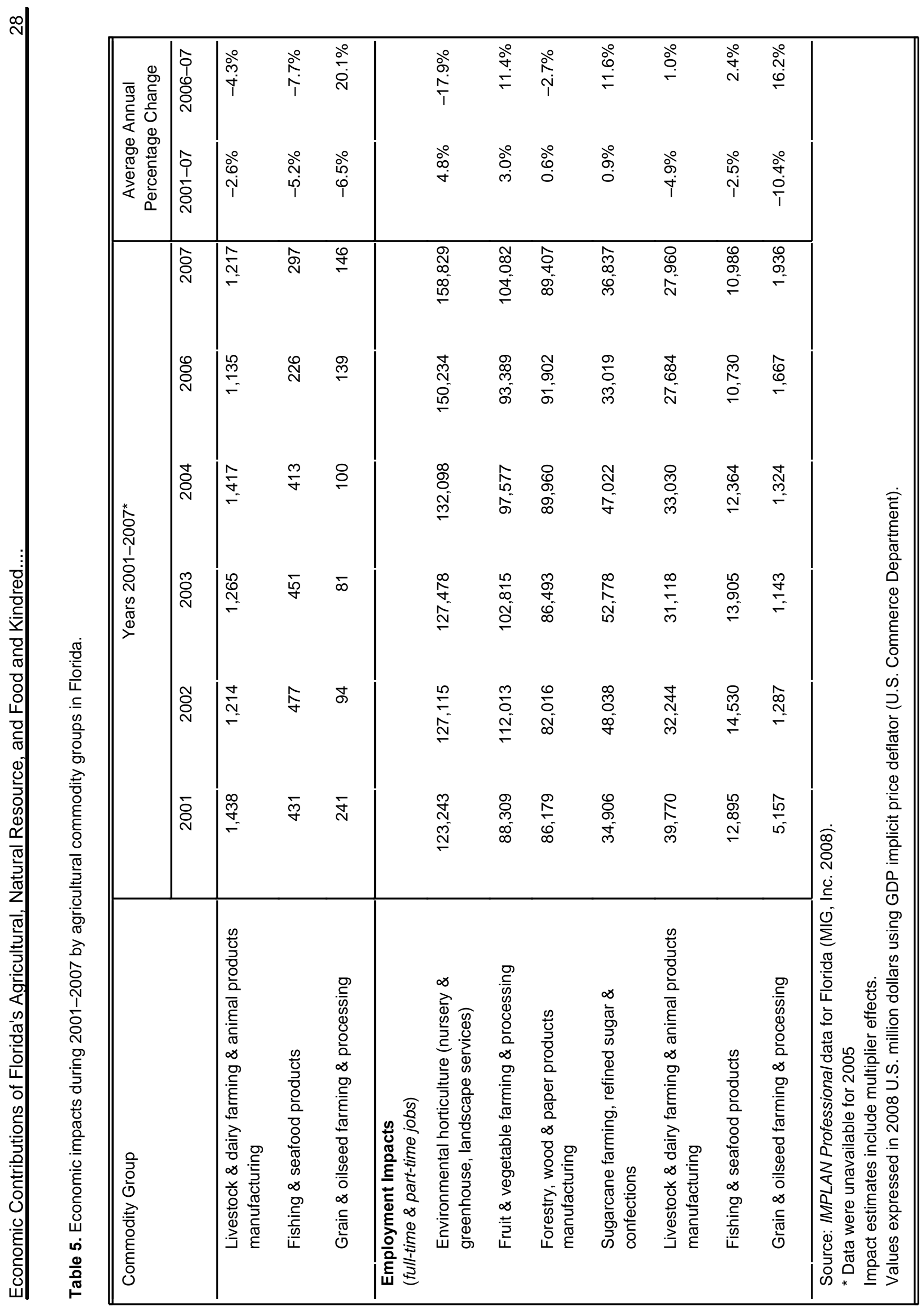

